\title{
Growth and physiological response of Kandelia obovata and Bruguiera sexangula seedlings to aluminum stress
}

\author{
$\mathrm{Li} \mathrm{Ma}^{1,2} \cdot$ Shengchang Yang ${ }^{1}$
}

Received: 21 May 2021 / Accepted: 30 November 2021 / Published online: 29 January 2022

(c) The Author(s) 2021

\begin{abstract}
The role of mangroves as a biogeochemical buffer for heavy metal pollutants in coastal wetlands has been demonstrated, but knowledge gaps still exist on the tolerant capacity of mangroves to aluminum (Al). This study assessed the growth and physiological response of viviparous mangroves Kandelia obovata and Bruguiera sexangula to Al stress. The two mangrove seedlings were treated with $\mathrm{AlCl}_{3}$ at concentrations of 0 (as control) to $100 \mathrm{mmol} \mathrm{L}$, and the impact of $\mathrm{Al}$ on their growth and antioxidant parameters were determined. Additionally, the accumulation and translocation of metal elements were estimated in B. sexangula seedlings under relative long-term Al stress. K. obovata appeared to survive with a tolerance potential of $10 \mathrm{mmol} \mathrm{L}^{-1} \mathrm{AlCl}_{3}$, whereas $B$. sexangula had a higher tolerant ability of $50 \mathrm{mmol} \mathrm{L}^{-1} \mathrm{AlCl}_{3}$. Both root elongation and seedling growth were inhibited by $\mathrm{Al}$ stress. The exposure to $25-100 \mathrm{mmol} \mathrm{L}^{-1} \mathrm{AlCl}_{3}$ induced increases in membrane lipid peroxidation and osmoprotectant molecule (proline) in mangrove seedlings. Both mangrove seedlings revealed significant changes in antioxidant enzyme activities that were attributed to $\mathrm{Al}$ stress-induced oxidative damages. The activities of superoxide dismutase, catalase, peroxidase, and/or ascorbate peroxidase were differently impacted by the treatment time (7 days for short term versus 60 days for long term) and $\mathrm{AlCl}_{3}$ concentrations in K. obovata and B. sexangula seedlings. For B. sexangula seedlings, $\mathrm{Al}$ accumulation was in an order root $>$ leaf $>$ stem, whereas the translocation of metal elements in the aboveground tissues (leaf and stem) was differently impacted by Al stress. In conclusion, this study provides insights into different Al-tolerant abilities operated in two mangrove species that are widespread in coastal wetlands of China.
\end{abstract}

Keywords Aluminum $\cdot$ Kandelia obovata $\cdot$ Bruguiera sexangula $\cdot$ Antioxidant enzyme $\cdot$ Metal element

\section{Introduction}

Anthropogenic activity has resulted in increases in the carbon dioxide $\left(\mathrm{CO}_{2}\right)$ release and the global atmospheric $\mathrm{CO}_{2}$ concentration in the past two centuries (Siegenthaler et al. 2005; Le Quéré et al. 2015; NOAA/ESRL 2019). A large proportion of excessive $\mathrm{CO}_{2}$ dissolved in the ocean and coastal waters is causing acidification (Sabine et al. 2004; Doney et al. 2009; Cai et al. 2011; Garilli et al. 2015;

Responsible Editor: Gangrong Shi

Shengchang Yang

scyang@xmu.edu.cn

1 Key Laboratory of the Coastal and Wetland Ecosystem (Ministry of Education), College of the Environment and Ecology, Xiamen University, Xiamen, China

2 Department of Chemical Engineering, Chengde Petroleum College, Chengde, China
Kwiatkowski et al. 2016; USEPA 2020). As a special type of tropical forests growing in tidal flooded coastal areas, mangrove forests are salt-tolerant and submerge-resistant (Ball et al. 1997; Chen and Wang 2017), and their unique distribution at the transition zone between terrestrial and aquatic environments makes them easily impacted by costal acidification (Sippo et al. 2016). Mangrove soils are neutral to slightly acidic due to the sulfur-reducing bacteria, and the acid sulfate soils are rich in aluminum oxide $\left(\mathrm{Al}_{2} \mathrm{O}_{3}\right)$ (Sparks 2003; Alongi 2005; Blake 2005; Bleam 2012). Because the amounts of dissolved aluminum cations $\left(\mathrm{Al}^{3+}\right)$ are significantly enhanced and released compared with other heavy metals, high concentrations of mobile aluminum $(\mathrm{Al})$ has become a potential pressure for plants (Cook et al. 2000; Pred and Cox 2002; Ramos e Silva et al. 2006).

Previous studies have demonstrated that mangrove seedlings are able to grow under very high concentrations of heavy metals (Walsh et al. 1979; MacFarlane and Burchett 2002; Miao et al. 2007; Ravikumar et al. 2007; Dai et al. 
2017) and salt stress (Takemura et al. 2000; Wang et al. 2014; Xing et al. 2019), although with negative effects on the growth. Mangroves have a high accumulation capability of metals, which can retain and provide a biogeochemical buffer for heavy metal pollutants (Tam 1998; Jones et al. 2000; MacFarlane and Burchett 2000; MacFarlane et al. 2003; Ramos e Silva et al. 2006; MacFarlane et al. 2007; Zhou et al. 2010). Mangroves are highly capable of uptake of metals and nutrients via root system from coastal sediments (MacFarlane et al. 2007; Marchand et al. 2016), which provides them a key role in phytoremediation (Agoramoorthy et al. 2008). Mature mangroves are known to be a particular ecosystem that can buffer coastal acidification (Sippo et al. 2016), which may be categorized as $\mathrm{Al}$ accumulator plants (Kombo et al. 2005; Isyrini 2014). Yet little is known regarding the effects of $\mathrm{Al}$ on mangroves, particularly under acidic environments. To our knowledge, no research has confirmed whether mangrove seedlings, when grown under high concentrations of $\mathrm{Al}$, behave the same as existing mature mangroves. Thus, the evaluation on the adaptation capability of mangrove seedlings is important. Until now, the impact of $\mathrm{Al}$ on the storage and transport of other major and trace elements, classified as macro-nutrients ( $\mathrm{Na}, \mathrm{K}, \mathrm{Mg}$, and $\mathrm{Ca}$ ) and trace metals $(\mathrm{Mn}, \mathrm{Fe}, \mathrm{Cu}$, and $\mathrm{Zn}$ ), respectively, in the mangrove seedlings remains unknown.

Aluminum adversely affects the germination of seeds and plant growth, such as inhibition of root elongation, seedling chlorosis, changing enzyme activities in various metabolic pathways, and affecting synthesis of proline and novel proteins (Samac and Tesfaye 2003; Tamás et al. 2003; Sivaguru et al. 2003; Fukuda et al. 2007; Chandra and Keshavkant 2021). It has been demonstrated that the formation of reactive oxygen species (ROS), such as hydrogen peroxide $\left(\mathrm{H}_{2} \mathrm{O}_{2}\right)$, superoxide $\left(\mathrm{O}_{2}^{-}\right)$, and hydroxyl $(\mathrm{OH})$ radicals, is stimulated by Al stress (Nahar et al. 2016; Al Mahmud et al. 2019; Devi et al. 2020). In order to protect cells from excessive ROS stress, antioxidant enzymes including superoxide dismutase (SOD), catalase (CAT), peroxidases (POD), and ascorbate peroxidase (APX) are induced to avoid oxidative damages (Tam and Wong 1996; MacFarlane and Burchett 2001; Zhang et al. 2007; Caregnato et al. 2008; Liu et al. 2009; Huang and Wang 2010; Wei et al. 2010). However, information on the growth response to $\mathrm{Al}$ stress and its induction of oxidative stress is scarce in mangrove seedlings. Based on previous research results that indicate that mangrove seedlings are able to grow under very high concentrations of heavy metals and salt stress, we hypothesized that similar tolerance and adaptive characteristics may occur in mangrove seedlings to high $\mathrm{Al}$ concentrations: (1) mangrove seedlings exposed to acidic conditions with elevated $\mathrm{Al}$ concentrations can survive, but with some disruptions in seedling growth, and (2) antioxidant enzymes in seedlings are activated to defend $\mathrm{Al}$-induced oxidative stress during natural growth.

Therefore, in order to elucidate the effects of $\mathrm{Al}$ stress on the growth and adaptation capability of mangrove seedlings, a laboratory study was conducted by culturing propagules of two natural viviparous mangroves and subjecting them to a range of aluminum chloride $\left(\mathrm{AlCl}_{3}\right)$ treatments. Kandelia obovata (S., L.) Yong and Bruguiera sexangula (L.) Poir. are two main mangroves belonging to salt-excluding species (i.e., species that exclude salt at the roots), which are of high biomass among mangroves in the costal wetland ecosystem of China (Chen et al. 2009; Ye et al. 2013) and are well tolerant of adverse environmental conditions ( $\mathrm{Lu}$ et al. 2012; Chen et al. 2017). The main objectives of this study are (1) to evaluate the response of the two viviparous mangrove seedlings to $\mathrm{Al}$ stress, including their growth, lipid peroxidation levels, and osmotic stress (indicated by proline contents), especially the activities of antioxidant enzymes involved in ROS scavenging; and (2) to determine the accumulation and translocation of metal elements within tissues of mangrove seedlings after relative long-term $\mathrm{Al}$ stress treatments.

\section{Materials and methods}

\section{The sampling area}

The sampling site for mangrove propagules is characterized with good water quality, non-metal pollution, and non-acid sulfate soil. Mature $K$. obovata propagules were collected from the Mangrove Nature Reserves located in the Jiulong River estuary in Fugong Town $\left(24^{\circ} 26^{\prime} \mathrm{N}, 117^{\circ} 54^{\prime} \mathrm{E}\right)$, Longhai County, Zhangzhou City, Fujian Province, China. The area belongs to the southern subtropical maritime climate, with a mean annual air temperature of $21.0{ }^{\circ} \mathrm{C}$ (Ye et al. 2013) and annual precipitation of $1,450 \mathrm{~mm}$. Regular semi-diurnal tides with an average salinity of water is 17.1 psu (Chen et al. 2007). The sediment in this area is primarily composed of silt and sand with $\mathrm{pH}$ values of 5.5-7.1 ( $\mathrm{Li}$ and Ye 2014). Mature B. sexangula propagules were collected from the Mangrove Nature Reserves located in the Qinglan harbor, Wenchang River estuary $\left(19^{\circ} 34^{\prime} \mathrm{N}, 110^{\circ} 24^{\prime} \mathrm{E}\right)$, Wenchang City, Hainan Province, China. The mean annual temperature and precipitation at the site are $24.3{ }^{\circ} \mathrm{C}$ and $1,975 \mathrm{~mm}$, respectively, with a rainy season between May and October. Irregular diurnal tides with an average salinity of water are $>30 \mathrm{psu}$. The $\mathrm{pH}$ value of the near shore soils ranges from 4.9-6.2. 


\section{Experiments}

\section{Propagation and germination}

The laboratory study was conducted in an indoor nursery at the Key Laboratory of the Coastal and Wetland Ecosystem (Ministry of Education), Xiamen University, China. Healthy and mature $K$. obovata propagules with lengths of $20.80 \pm 0.59 \mathrm{~cm}$ and fresh weights (FWs) of $12.17 \pm 1.69 \mathrm{~g}$ and $B$. sexangula propagules with lengths of $8.23 \pm 1.04 \mathrm{~cm}$ and FWs of $12.20 \pm 0.68 \mathrm{~g}$ were randomly planted in the plastic sifters with pots, with 5 propagules in each sifter. Each sifter and pot were filled with $2.5 \mathrm{~kg}$ of washed river sand (diameter: 2-4 mm). Artificial seawater containing Hoagland's culture solution was used for propagation and treatments, with a salinity of 3.0 psu by dissolving $85.5 \mathrm{mM}$ $\mathrm{NaCl}$. This salinity level is considered suitable for the development of mangroves that are grown in a nursery environment (Downton 1982; Takemura et al. 2000).

\section{Al Treatment set-up}

After 1 month of natural growth, $K$. obovata and B. sexangula seedlings were treated by $\mathrm{Al}$ in the form of $\mathrm{AlCl}_{3}$ solution. The selection of chloride $(\mathrm{Cl})$ metals was based on the consideration that this form is tolerable by mangroves, therefore reducing the toxicity of the $\mathrm{Cl}$ ions (salt stress) (Burchett et al. 1984; Takemura et al. 2000; Parida et al. 2004; Yan and Chen 2007; Wang et al. 2014; Hossain et al. 2017; Basyuni et al. 2018). Due to little is known regarding the effects of $\mathrm{Al}$ on mangrove seedlings, the chosen concentrations of $\mathrm{AlCl}_{3}$ were primarily based on the $\mathrm{Al}$ limit reported on representative terrestrial plants in previous studies (Cakmak and Horst 1991; Darkó et al. 2004; Morita et al. 2008), and the tolerance range to heavy metals (Walsh et al. 1979; MacFarlane and Burchett 2002; Miao et al. 2007; Ravikumar et al. 2007; Dai et al. 2017) and salt stress ( $\mathrm{NaCl})$ on laboratory-grown mangrove seedlings (Takemura et al. 2000; Wang et al. 2014; Xing et al. 2019).

We designed $\mathrm{AlCl}_{3}$ treatment experiments using a relative lower concentration of $0-1.0 \mathrm{mmol} \mathrm{L}^{-1}$ and a relative higher concentration of $0-100 \mathrm{mmol} \mathrm{L}^{-1}$. The $\mathrm{AlCl}_{3}$ treatments at 0-1.0 $\mathrm{mmol} \mathrm{L}^{-1}$ were applied to $K$. obovata seedlings, whereas $\mathrm{AlCl}_{3}$ treatments with a concentration gradient of 0 (as control), 10, 25, 50, 75, and $100 \mathrm{mmol} \mathrm{L}^{-1}$ were applied to both $K$. obovata and $B$. sexangula seedlings. $\mathrm{AlCl}_{3}$ solution with a final $\mathrm{pH}$ value of 4.2 was added to each pot in each treatment, with four replicates for each treatment. Culture solutions were renewed weekly to maintain a relatively constant $\mathrm{AlCl}_{3}$ concentration during the experimental period. All cultivations were kept in an indoor nursery with an air temperature of $25-32{ }^{\circ} \mathrm{C}$. The duration of the treatment was up to $7-90$ days, depending on the mortality of the seedlings. Additionally, the short-term ( $168 \mathrm{~h}=7$ days) $\mathrm{AlCl}_{3}$ treatments at concentrations of 25 and $100 \mathrm{mmol} \mathrm{L}^{-1}$ were applied to $K$. obovata seedlings to estimate the effect of $\mathrm{Al}$ on lipid peroxidation and antioxidant enzyme activities.

\section{Parameter analysis}

\section{Growth parameters}

Growth measurements from each set of seedlings included apparent healthy conditions, survival of seedlings, the height of seedling, and the average root length. The stem height of seedlings was measured from the top of the propagules where the stem emerged to the bottom of the most distal opened pairs of leaves. The root length increment (final root length minus initial root length) was measured to evaluate $\mathrm{Al}$-induced rootgrowth inhibition.

\section{Lipid peroxidation and osmotic stress parameters}

The level of lipid peroxidation that was expressed as malondialdehyde (MDA) content was evaluated by the thiobarbituric assay described by Shah et al. (2001) with some modifications. Briefly, $1.0 \mathrm{~g}$ of fresh leaf or root was homogenized in $10 \mathrm{~mL}$ of phosphate buffer ( $\mathrm{pH}: 7.8$ ) on an ice bath and centrifuged at $15,000 \mathrm{~g}$ and $4{ }^{\circ} \mathrm{C}$ for $20 \mathrm{~min}$. One milliliter of supernatant was mixed with $1.0 \mathrm{~mL}$ of $0.5 \%$ 2-thiobarbituric acid (TBA) in $10 \%$ trichloroacetic acid (TCA) (w/v) solution. After being incubated at $95{ }^{\circ} \mathrm{C}$ for $15 \mathrm{~min}$, the reaction was terminated by cooling and the mixture was centrifuged at $4,000 \mathrm{rpm}$ for $20 \mathrm{~min}$. The absorbance was measured at 532 and $600 \mathrm{~nm}$, and the non-specific absorbance at $600 \mathrm{~nm}$ was subtracted from the $532 \mathrm{~nm}$ absorbance. MDA contents were calculated by using an extinction coefficient $(\varepsilon)$ of $155 \mathrm{mmol} \mathrm{L}^{-1} \mathrm{~cm}^{-1}$ and were expressed as nmol g ${ }^{-1}$ or $\mathrm{mg} \mathrm{g}^{-1}$ of FW.

The osmotic stress indicated by free proline content was determined with a ninhydrin colorimetric assay according to Ábrahám et al. (2010). Plant materials were homogenized in $3 \%$ sulfosalicyclic acid ( $5 \mu \mathrm{L} \mathrm{mg}^{-1}$ of FW) on an ice bath and centrifuged at $11,500 \mathrm{~g}$ for $5 \mathrm{~min}$. One hundred microliters of supernatant was mixed with $200 \mu \mathrm{L}$ of glacial acetic acid and $200 \mu \mathrm{L}$ of acidic ninhydrin. After incubating the mixture at $96{ }^{\circ} \mathrm{C}$ for $60 \mathrm{~min}$ followed by quick cooling, $1 \mathrm{~mL}$ of toluene was added and stirred for $30 \mathrm{~s}$. After $5 \mathrm{~min}$, the chromophore containing toluene was measured spectrophotometrically at $520 \mathrm{~nm}$. The proline content was determined using a standard curve and calculated on the FW basis.

\section{Enzyme extraction and estimation of antioxidant enzyme activities}

Methods taken from references were optimized before being applied to K. obovata and B. sexangula. Enzyme extraction 
was prepared following the method of Gossett et al. (1994). Soluble protein contents were determined according to Bradford (1976) using bovine serum albumin (BSA, Sigma) as the standard. Absorbencies were measured with a UVICAM UV-300 (Thermo Spectronic, USA) spectrophotometer.

SOD activity was measured based on the method described by Dazy et al. (2009). The photochemical reduction of nitro blue tetrazolium (NBT) was inhibited and the level of inhibition was used to quantify SOD activity. The reaction mixture contained $100 \mu \mathrm{L}$ of plant extract, $100 \mu \mathrm{L}$ of methionine $(130 \mathrm{mM}), 100 \mu \mathrm{L}$ of riboflavin $(600 \mathrm{mM})$, $100 \mu \mathrm{L}$ of NBT $(22.5 \mathrm{mM})$, and $600 \mu \mathrm{L}$ of $125 \mathrm{mM}$ potassium-phosphate buffer (pH: 7.8). After 15 min of illumination reaction (ambient light), the absorbance was measured spectrophotometrically at $560 \mathrm{~nm}$ and $25^{\circ} \mathrm{C}$. Unit of SOD activity was defined as the amount of enzyme required to cause $50 \%$ inhibition of the rate of NBT reduction measured at $560 \mathrm{~nm}$ under experimental conditions.

POD activity was determined according to Yin et al. (2005) with modifications. The reaction mixture contained $100 \mu \mathrm{L}$ of plant extract, $1.5 \mathrm{~mL}$ of $62.5 \mathrm{mM}$ sodium phosphate buffer (pH: 7.8), and $20 \mathrm{mM}$ 2-methoxyphenol. The reaction was initiated by adding $10 \mu \mathrm{L}$ of hydrogen peroxide $\left(\mathrm{H}_{2} \mathrm{O}_{2}\right)(100 \mathrm{mM})$ at $25{ }^{\circ} \mathrm{C}$ for $5 \mathrm{~min}$. POD activity was evaluated by measuring the rate of increase in absorbance at $470 \mathrm{~nm}$.

CAT activity was determined according to Chaoui et al. (1997) with modifications. The reaction mixture contained $100 \mu \mathrm{L}$ of plant extract and $900 \mu \mathrm{L}$ of $62.5 \mathrm{mM}$ sodium phosphate buffer ( $\mathrm{pH}:$ 7.8) with $100 \mathrm{mM} \mathrm{H}_{2} \mathrm{O}_{2}$. The reaction was initiated by adding $10 \mu \mathrm{L}$ of $\mathrm{H}_{2} \mathrm{O}_{2}(100 \mathrm{mM})$ at $25^{\circ} \mathrm{C}$ for $5 \mathrm{~min}$. CAT activity was evaluated by measuring the rate of disappearance of $\mathrm{H}_{2} \mathrm{O}_{2}$ at $240 \mathrm{~nm}$ with a molar extinction coefficient $(\varepsilon)$ of $36.6 \mathrm{mM}^{-1} \mathrm{~cm}^{-1}$.

APX activity was determined according to GarciaLimones et al. (2002). The reaction mixture contained 100 $\mu \mathrm{L}$ of plant extract, $100 \mu \mathrm{L}$ of ascorbate solution $(5 \mathrm{mM})$, $100 \mu \mathrm{L}$ of $\mathrm{H}_{2} \mathrm{O}_{2}(100 \mathrm{mM}), 100 \mu \mathrm{L}$ of EDTA solution ( $1 \mathrm{mM})$, and $125 \mathrm{mM}$ potassium-phosphate buffer $(\mathrm{pH}$ : 7.0). APX activity was evaluated by measuring the rate of ascorbate oxidation at $290 \mathrm{~nm}$ with an extinction coefficient (ع) of $2.8 \mathrm{mM}^{-1} \mathrm{~cm}^{-1}$.

\section{Metal element analysis}

For metal element analysis, samples of the leaf, stem, and root were collected, dried overnight at $85{ }^{\circ} \mathrm{C}$, and then ground into fine powder with a ball milling instrument. Using a microwave digestion system (MARS-240/50, CEM, USA), $0.1 \mathrm{~g}$ of each powder sample was digested with $4 \mathrm{~mL}$ of nitric acid $\left(\mathrm{HNO}_{3}\right)$ and $1 \mathrm{~mL}$ of $\mathrm{H}_{2} \mathrm{O}_{2}(30 \%)$. One hour later, the solution was transferred to a capacity bottle and filled with ultrapure water (UPW) to $100 \mathrm{~mL}$. Metal elements including $\mathrm{Na}, \mathrm{Mg}, \mathrm{Al}, \mathrm{K}, \mathrm{Ca}, \mathrm{Mn}, \mathrm{Fe}, \mathrm{Cu}$, and $\mathrm{Zn}$ in $B$. sexangula seedlings were measured by inductively coupled plasma-mass spectrometry (ICP-MS, PE, USA). Each sample was repeated 3-4 times.

\section{Statistical analysis}

Mean and standard deviation (SD) values of replicate seedling samples under each experiment group were calculated. All data obtained were subjected to one-way analysis of variance (ANOVA) (SPSS 18.0 for single-factor ANOVA). Statistical significance was assigned at $P<0.05$. The relationships between variables were determined via correlation analysis. All graphs were plotted using SigmaPlot (version 10.0).

The enrichment factor (EF) of metals in each tissue of mangrove seedlings (i.e., leaf, stem, and root) was used to evaluate the elemental enrichment of mangrove tissues from the environment (i.e., total metal in culture solution). The EF of metal ( $\mathrm{Al}$ in the case of this study) was determined using the ratio of the concentration of $\mathrm{Al}$ in a given sample (mangrove tissues) relative to the $\mathrm{AlCl}_{3}$ substance in the culture solution (i.e., $\mathrm{Al}_{\text {sample }} / \mathrm{Al}_{\text {substance }}$ (Costa et al. 2020). The mobility of metal that controls the distribution and accumulation of metals in mangrove tissues (MacFarlane and Burchett 2002) was assessed by the translocation factor (TF). The TF was determined by the ratio of metal concentration between the aboveground tissue (i.e., leaf and stem) and the underground tissue (i.e., root) (MacFarlane et al. 2007).

\section{Results}

\section{Growth response of $K$. obovata and $B$. sexangula seedlings to aluminum stress}

After relative long-term (90 days) treatments on $K$. obovata seedlings by low concentrations of $\mathrm{AlCl}_{3}(0.0625-1.0 \mathrm{mmol}$ $\mathrm{L}^{-1}$ ), a significant decrease in average root length by 17.3-22.2\% relative to that of control was observed, whereas there was no significant difference in seedling height (Fig. 1a). After being treated with high concentrations of $\mathrm{AlCl}_{3}\left(10-100 \mathrm{mmol} \mathrm{L}^{-1}\right)$, the seedlings growing under $10 \mathrm{mmol} \mathrm{L}^{-1} \mathrm{AlCl}_{3}$ showed no significant difference in growth conditions compared to that of control within 30 days. Whereas the natural growth of $K$. obovata seedlings was significantly inhibited by $25-100 \mathrm{mmol} \mathrm{L}^{-1} \mathrm{AlCl}_{3}$ treatment, showing curled and wilted leaves with observed brown lesions, the number of new leaves also reduced 33.3-50.0\% compared to that of control, the root tips turned black, and the whole roots became brittle. All (100\%) of the seedlings were injured and eventually died within 7-15 days. 


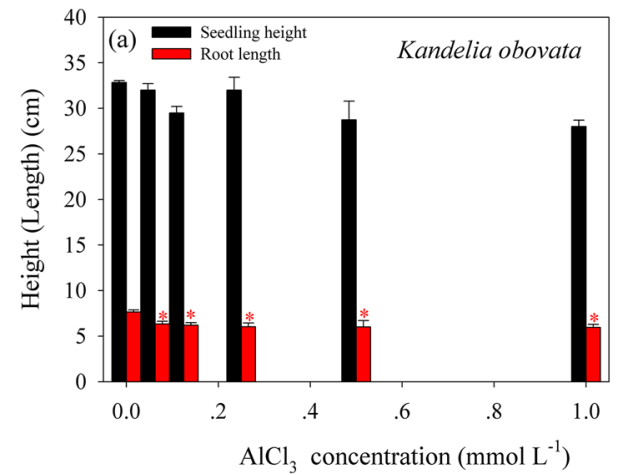

Fig. 1 Growth response of $K$. obovata seedlings after long-term (90 days) treatments by low concentrations of $\mathrm{AlCl}_{3}(0-1.0 \mathrm{mmol}$ $\left.\mathrm{L}^{-1}\right)(\mathbf{a})$, and growth response of $B$. sexangula seedlings that treated with 60 days by high concentrations of $\mathrm{AlCl}_{3}\left(0-50.0 \mathrm{mmol} \mathrm{L}^{-1}\right)(\mathbf{b})$.

The natural growth of $B$. sexangula seedlings was significantly inhibited by 100 and $75 \mathrm{mmol} \mathrm{L}^{-1} \mathrm{AlCl}_{3}$ treatments, and they finally died of root necrosis within 7 and 15 days, respectively. Under a $\mathrm{AlCl}_{3}$ concentration of $50 \mathrm{mmol} \mathrm{L}^{-1}$, the seedling growth became gradually stunted. Approximately 60 days later, a significant decrease in seedling height by $16.3 \%$ and $33.2 \%$ compared to that of control was observed for seedlings treated by 25 and $50 \mathrm{mmol} \mathrm{L}^{-1} \mathrm{AlCl}_{3}$, respectively (Fig. 1b).

\section{MDA and proline contents in $K$. obovata and $B$. sexangula seedlings}

The lipid peroxidation level (expressed as MDA content) and osmotic stress response (indicated by proline content) in $K$. obovata seedlings under short-term $(168 \mathrm{~h})$ treatments with 25 and $100 \mathrm{mmol} \mathrm{L}^{-1} \mathrm{AlCl}_{3}$ are presented in Fig. 2. The contents of MDA were significantly increased in the leaf after 2-h treatment under both $\mathrm{AlCl}_{3}$ concentrations (Fig. 2a), while there were no significant changes in MDA contents in the root (Fig. 2a). Overall, the MDA content was significantly higher after being stressed by $100 \mathrm{mmol} \mathrm{L}^{-1} \mathrm{AlCl}_{3}$ than that by $25 \mathrm{mmol} \mathrm{L}^{-1} \mathrm{AlCl}_{3}(P<0.05)$. The proline contents were continuously increased in the leaf after $12 \mathrm{~h}$ of treatment with 25 and $100 \mathrm{mmol} \mathrm{L}^{-1} \mathrm{AlCl}_{3}$ (Fig. 2b), and the increasing proline contents in the root was also observed after $72 \mathrm{~h}$ of treatment (Fig. 2b).

Both the MDA and proline contents in B. sexangula seedlings that under a long-term (60 days) treatment with 0-50 mmol L${ }^{-1} \mathrm{AlCl}_{3}$ are presented in Fig. 3. The MDA contents in $B$. sexangula seedlings were significantly increased in both the leaf and root under $50 \mathrm{mmol} \mathrm{L}^{-1} \mathrm{AlCl}_{3}$ treatment (Fig. 3a), which was 1.3 and 1.9 times to that of control, respectively. The proline contents in both the leaf and root were also significantly increased in $B$. sexangula seedlings that were treated with 25 or $50 \mathrm{mmol} \mathrm{L}^{-1} \mathrm{AlCl}_{3}$

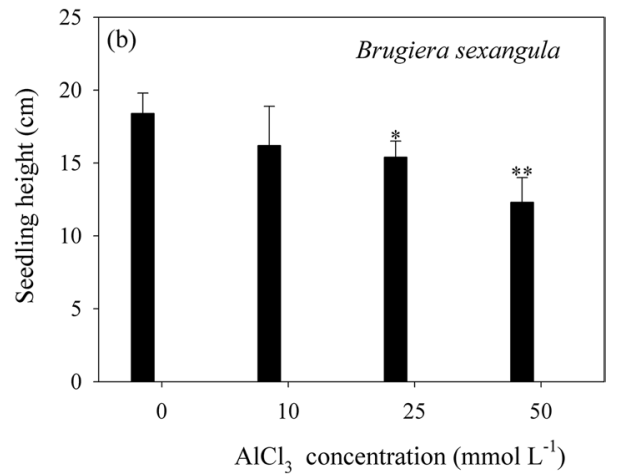

Values are mean $\pm \mathrm{SD}$. “*” above the bar indicates a significant difference versus $0 \mathrm{mmol} \mathrm{L}^{-1} \mathrm{AlCl}_{3}$ (control) at $P<0.05$, and "**" above the bar indicates a significant difference versus $0 \mathrm{mmol} \mathrm{L}^{-1} \mathrm{AlCl}_{3}$ (control) at $P<0.01$

(Fig. 3b), and the proline content was significantly higher under $50 \mathrm{mmol} \mathrm{L}^{-1} \mathrm{AlCl}_{3}$ than that treated by $25 \mathrm{mmol} \mathrm{L}^{-1}$ $\mathrm{AlCl}_{3}(P<0.01)$.

\section{Antioxidant enzyme activities in $K$. obovata and $B$. sexangula seedlings in response to aluminum}

The antioxidant enzyme activities in response to the oxidative stress that was induced by short-term $(168 \mathrm{~h}) \mathrm{AlCl}_{3}$ treatments in $K$. obovata seedlings are presented in Fig. 4. Results showed that antioxidant enzyme activities varied in $K$. obovata seedlings subjected to different $\mathrm{AlCl}_{3}$ treatments. SOD activity was increased after $6 \mathrm{~h}$ of $25 \mathrm{mmol} \mathrm{L}^{-1} \mathrm{AlCl}_{3}$ treatment, with the maximum value observed after $24 \mathrm{~h}$ in the leaf (Fig. 4a), whereas for that of $100 \mathrm{mmol} \mathrm{L}^{-1} \mathrm{AlCl}_{3}$ treatment, SOD activity was continuously decreased with a short period of increase after 6-48 h in the leaf (Fig. 4a). SOD activity in the root was significantly decreased after $72 \mathrm{~h}$ of 25 or $100 \mathrm{mmol} \mathrm{L}^{-1} \mathrm{AlCl}_{3}$ treatment (Fig. 4a). Similarly, POD activity was significantly increased in the leaf after $6 \mathrm{~h}$ of 25 or $100 \mathrm{mmol} \mathrm{L}^{-1} \mathrm{AlCl}_{3}$ treatment (Fig. 4b), and POD activity in the root was significantly increased within 120 and $168 \mathrm{~h}$ after being treated with 100 and $25 \mathrm{mmol} \mathrm{L}^{-1} \mathrm{AlCl}_{3}$, respectively (Fig. 4b). Overall, POD activity was higher under $100 \mathrm{mmol} \mathrm{L}^{-1} \mathrm{AlCl}_{3}$ treatment than that under $25 \mathrm{mmol} \mathrm{L}^{-1} \mathrm{AlCl}_{3}(P<0.01)$. Furthermore, CAT activity was highly increased in the leaf after being treated by 25 or $100 \mathrm{mmol} \mathrm{L}^{-1} \mathrm{AlCl}_{3}$ for $2 \mathrm{~h}$, and decreased after 72 or $48 \mathrm{~h}$, with the maximum value observed after 6 or $2 \mathrm{~h}$, respectively (Fig. 4c). However, a significant decrease in CAT activity in the root was observed after $72 \mathrm{~h}$ of $\mathrm{AlCl}_{3}$ treatments (Fig. 4c), and CAT activity was higher under $25 \mathrm{mmol} \mathrm{L}^{-1} \mathrm{AlCl}_{3}$ than that treated by $100 \mathrm{mmol} \mathrm{L}^{-1} \mathrm{AlCl}_{3}$ $(P<0.05)$.

For $B$. sexangula seedlings obtained after a relative longterm (60 days) exposure to 10,25 , and $50 \mathrm{mmol} \mathrm{L}^{-1} \mathrm{AlCl}_{3}$ 
Fig. 2 Changes in MDA content (a) and free proline content (b) in the leaf and root of $K$. obovata seedlings under short-term $(168 \mathrm{~h})$ treatments with $25 \mathrm{mmol} \mathrm{L}^{-1}(25 \mathrm{mM}$, black bar) and $100 \mathrm{mmol} \mathrm{L}^{-1}$ (100 mM, red bar) $\mathrm{AlCl}_{3}$ Values are mean $\pm \mathrm{SD}$. “*” above the bar indicates a significant difference versus $0 \mathrm{~h}$ group (control) at $P<0.05$, and “**” above the bar indicates a significant difference versus $0 \mathrm{~h}$ group (control) at $P<0.01$
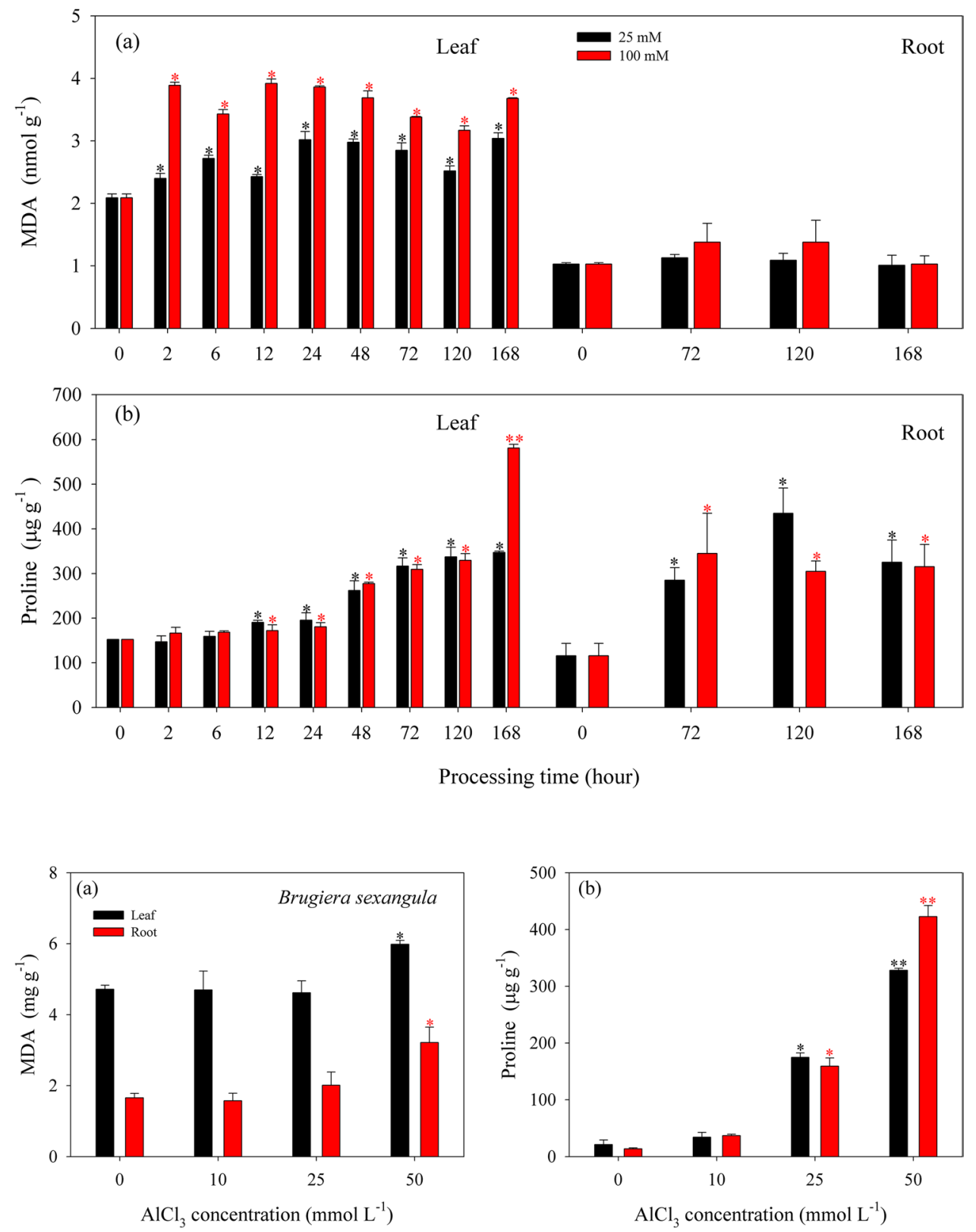

Fig. 3 MDA content (a) and proline content (b) in the leaf (black bar) and in the root (red bar) of $B$. sexangula seedlings that under a long-term (60 days) treatment with $0-50 \mathrm{mmol} \mathrm{L}^{-1}$ $\mathrm{AlCl}_{3}$. Values are mean $\pm \mathrm{SD}$. "*” above the bar indicates a significant difference versus 0 mmol L ${ }^{-1} \mathrm{AlCl}_{3}$ (control) at $P<0.05$, and "**" above the bar indicates a significant difference versus $0 \mathrm{mmol} \mathrm{L}^{-1} \mathrm{AlCl}_{3}$ (control) at $P<0.01$ treatments, APX activity was significantly increased in the leaf under $10-50 \mathrm{mmol} \mathrm{L}^{-1} \mathrm{AlCl}_{3}$ treatment, whereas increased activity in the root was only observed under $10 \mathrm{mmol} \mathrm{L}^{-1} \mathrm{AlCl}_{3}$ (Fig. 5a). SOD activity was increased in the leaf with the increasing $\mathrm{AlCl}_{3}$ concentrations (Fig. 5b); conversely, SOD activity was significantly decreased in the root under $50 \mathrm{mmol} \mathrm{L}^{-1} \mathrm{AlCl}_{3}$ (Fig. 5b). Compared to that of control, POD activity was significantly increased in the leaf, with the maximum observed under $25 \mathrm{mmol} \mathrm{L}^{-1} \mathrm{AlCl}_{3}$ (Fig. 5c). Additionally, a positive relationship between POD activity and $\mathrm{AlCl}_{3}$ concentration was observed in the root $(P<0.05)$ (Fig. 5c). In contrast, CAT activity was gradually decreased in both the leaf and root with the increasing $\mathrm{AlCl}_{3}$ concentrations (Fig. 5d). Notably, the activities of APX, SOD, and CAT were well correlated with MDA content in the leaf $(P<0.05)$, while SOD, POD, and CAT activities presented clear $\mathrm{AlCl}_{3}$ concentration-dependent relationships $(P<0.05)$.

\section{Metal element accumulation and translocation in $B$. sexangula seedlings}

The contents of nine metal elements were generally different in various tissues of $B$. sexangula seedlings under $\mathrm{AlCl}_{3}$ treatments (Fig. 6). The contents of elements were aluminum $(\mathrm{Al})$ of $0.38-2.37 \mathrm{mg} \mathrm{g}^{-1}$, sodium $(\mathrm{Na})$ of $10.33-17.84 \mathrm{mg} \mathrm{g}^{-1}$, potassium (K) of $8.48-16.75 \mathrm{mg} \mathrm{g}^{-1}$, magnesium $(\mathrm{Mg})$ of $0.69-2.09 \mathrm{mg} \mathrm{g}^{-1}$, calcium $(\mathrm{Ca})$ of 
Fig. 4 Changes in activities of SOD (a), POD (b), and CAT (c) in the leaf and root of Kandelia obovata seedlings that induced by short-term $(168 \mathrm{~h}) \mathrm{AlCl}_{3}$ treatments, $25 \mathrm{~mol} \mathrm{~L}^{-1}(25 \mathrm{mM}$, black bar) and $100 \mathrm{~mol} \mathrm{~L}^{-1}$ (100 mM, red bar). Values are mean \pm SD. "*” above the bar indicates a significant difference versus $0 \mathrm{~h}$ group (control) at $P<0.05$, and "***" above the bar indicates a significant difference versus $0 \mathrm{~h}$ group (control) at $P<0.01$
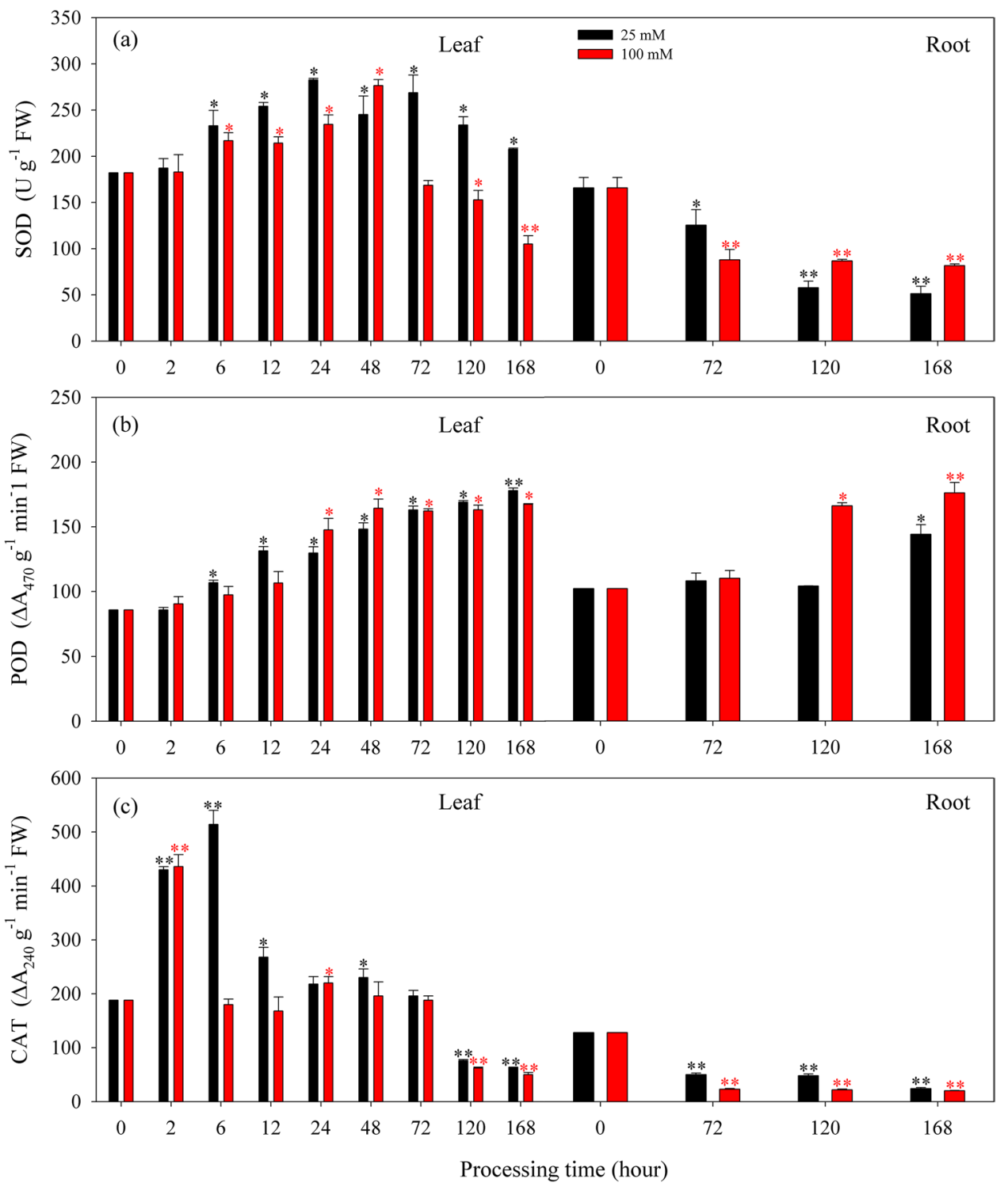

$3.04-7.96 \mathrm{mg} \mathrm{g}^{-1}$, manganese (Mn) of $0.08-0.56 \mathrm{mg} \mathrm{g}^{-1}$, iron $(\mathrm{Fe})$ of $0.25-1.20 \mathrm{mg} \mathrm{g}^{-1}$, copper $(\mathrm{Cu})$ of $0.71-1.81$ $\mu \mathrm{g} \mathrm{g}^{-1}$, and zinc (Zn) of 10.92-34.53 $\mu \mathrm{g} \mathrm{g}^{-1}$.

Aluminum was significantly accumulated in all tissues of B. sexangula seedlings by all $\mathrm{AlCl}_{3}$ treatments; the accumulation pattern of $\mathrm{Al}$ was root $>$ leaf $>$ stem (Fig. 6a and Table 1). Na was also significantly accumulated in the root under all $\mathrm{AlCl}_{3}$ treatments (Fig. 6b), whereas $\mathrm{K}$ was only accumulated in the root under $10 \mathrm{mmol} \mathrm{L}^{-1} \mathrm{AlCl}_{3}$, and in the stem under $50 \mathrm{mmol} \mathrm{L}^{-1} \mathrm{AlCl}_{3}$ (Fig. 6c). The accumulation of $\mathrm{Mg}$ in the root was inhibited by $10-25 \mathrm{mmol} \mathrm{L}^{-1}$ $\mathrm{AlCl}_{3}$ treatment, whereas a significantly increase in $\mathrm{Mg}$ was observed in the stem treated by $50 \mathrm{mmol} \mathrm{L}^{-1} \mathrm{AlCl}_{3}$ (Fig. 6d). The accumulation of $\mathrm{Ca}$ was significantly inhibited in the leaf, but increased in the root under $25-50 \mathrm{mmol} \mathrm{L}^{-1} \mathrm{AlCl}_{3}$ (Fig. 6e). The accumulation of Mn was significantly inhibited in the leaf, stem, and root under $10-50 \mathrm{mmol} \mathrm{L}^{-1} \mathrm{AlCl}_{3}$
(Fig. 6f). Similarly, the accumulation of Fe was decreased in both the leaf and stem under $10-25 \mathrm{mmol} \mathrm{L}^{-1} \mathrm{AlCl}_{3}$, and a decrease to $70.1 \%$ was observed in the root under $50 \mathrm{mmol}$ $\mathrm{L}^{-1} \mathrm{AlCl}_{3}$ (Fig. 6g). A decrease in $\mathrm{Cu}$ accumulation in the leaf and root under $\mathrm{AlCl}_{3}$ treatments was also observed, but not in the stem (Fig. 6h). The accumulation of $\mathrm{Zn}$ was significantly decreased in the leaf and stem by all $\mathrm{AlCl}_{3}$ treatments; however, it was increased in the root under $50 \mathrm{mmol}$ $\mathrm{L}^{-1} \mathrm{AlCl}_{3}$ (Fig. 6i).

The EFs of $\mathrm{AlCl}_{3}$ in $B$. sexangula tissues (leaf, stem, and root) are presented in Table 1. The values of EFs in the leaf, stem, and root were significantly decreased, accompanied by increasing $\mathrm{AlCl}_{3}$ concentrations in the substrate. Under the same $\mathrm{AlCl}_{3}$ level, the highest $\mathrm{EF}$ of $\mathrm{Al}$ was observed in the root, whereas the lowest one was in the stem. The EFs of $\mathrm{Al}$ in each fraction of $B$. sexangula seedlings under $10 \mathrm{mmol} \mathrm{L}^{-1} \mathrm{AlCl}_{3}$ varied from 2.92 to 12.28 , while those 
Fig. 5 Changes in activities of APX (a), SOD (b), POD (c), and CAT (d) in the leaf (black bar) and root (red bar) of $B$. sexangula seedlings by longterm (60 days) treatment with 0-50.0 $\mathrm{mmol} \mathrm{L}^{-1} \mathrm{AlCl}_{3}$. Values are mean \pm SD. "**" above the bar indicates a significant difference versus $0 \mathrm{mmol} \mathrm{L}^{-1} \mathrm{AlCl}_{3}$ (control) at $P<0.05$, and “**” above the bar indicates a significant difference versus $0 \mathrm{mmol}$ $\mathrm{L}^{-1} \mathrm{AlCl}_{3}$ (control) at $P<0.01$
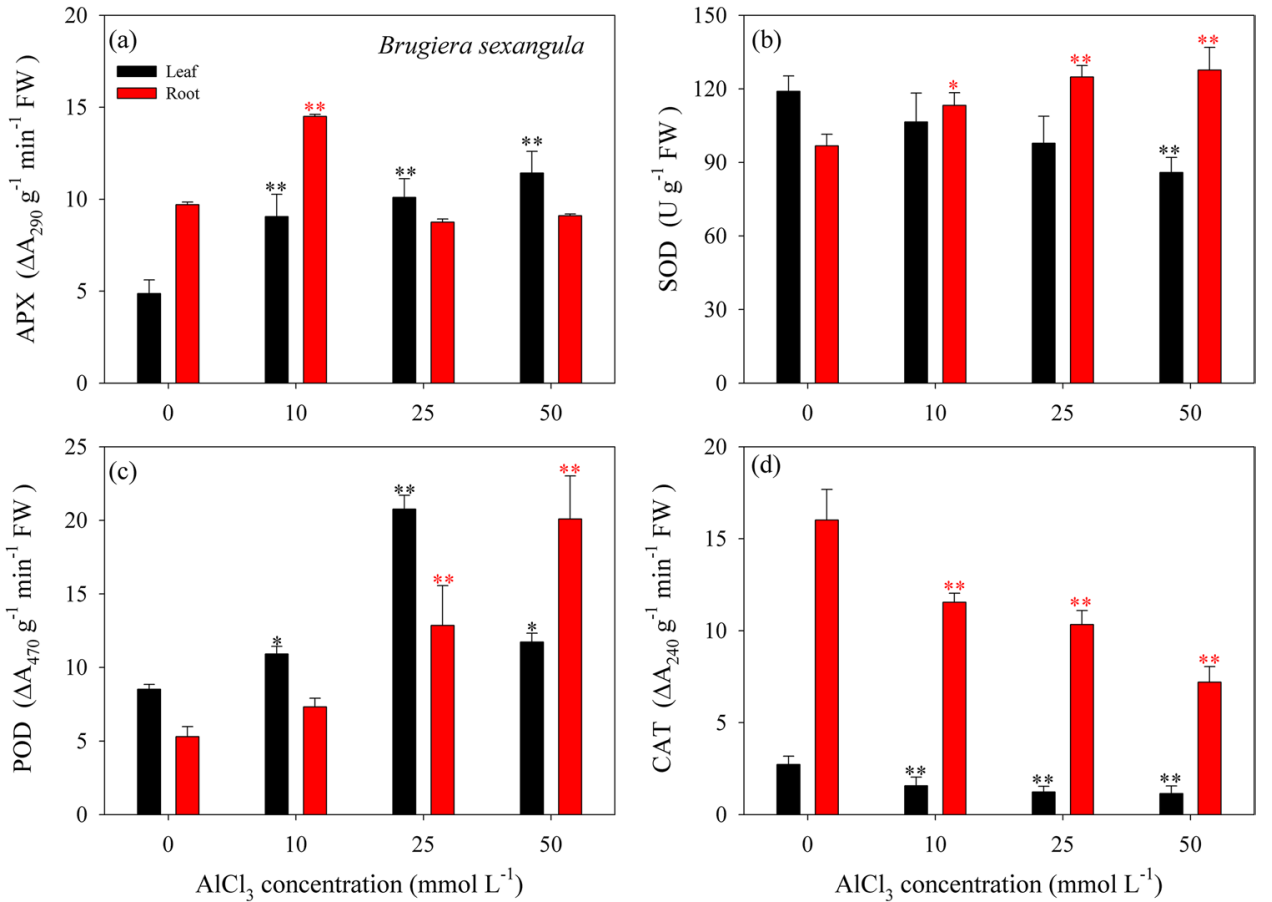

Fig. 6 The element content of $\mathrm{Al}(\mathbf{a}), \mathrm{Na}(\mathbf{b}), \mathrm{K}(\mathbf{c}), \mathrm{Mg}(\mathbf{d})$, $\mathrm{Ca}(\mathbf{e}), \mathrm{Mn}(\mathbf{f}), \mathrm{Fe}(\mathbf{g}), \mathrm{Cu}(\mathbf{h})$, and $\mathrm{Zn}$ (i) in B. sexangula tissues (leaf, stem, and root) under a long-term (60 days) treatment with $0-50.0 \mathrm{mmol} \mathrm{L}^{-1} \mathrm{AlCl}_{3}$. Note that the unit for $(\mathbf{a}-\mathbf{f})$ is $\left(\mathrm{mg} \mathrm{g}^{-1}\right)$, and unit for $(\mathbf{h}, \mathbf{i})$ is $\left(\mu \mathrm{g} \mathrm{g}^{-1}\right)$. Values are mean $\pm \mathrm{SD}$. "**" above the bar indicates a significant difference versus $0 \mathrm{mmol} \mathrm{L}{ }^{-1} \mathrm{AlCl}_{3}$ (control) at $P<0.05$, and "*** above the bar indicates a significant difference versus $0 \mathrm{mmol} \mathrm{L}^{-1} \mathrm{AlCl}_{3}$ (control) at $P<0.01$

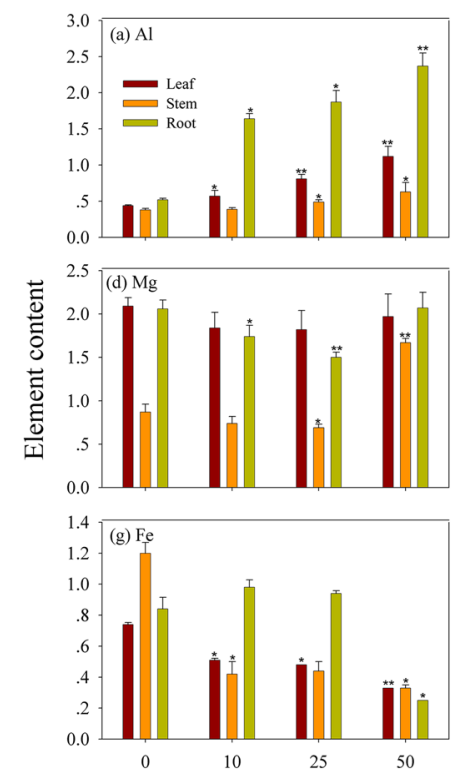

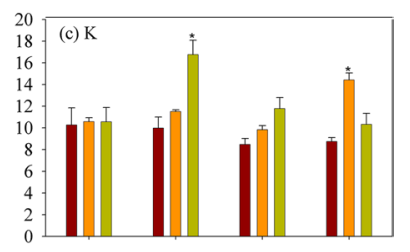
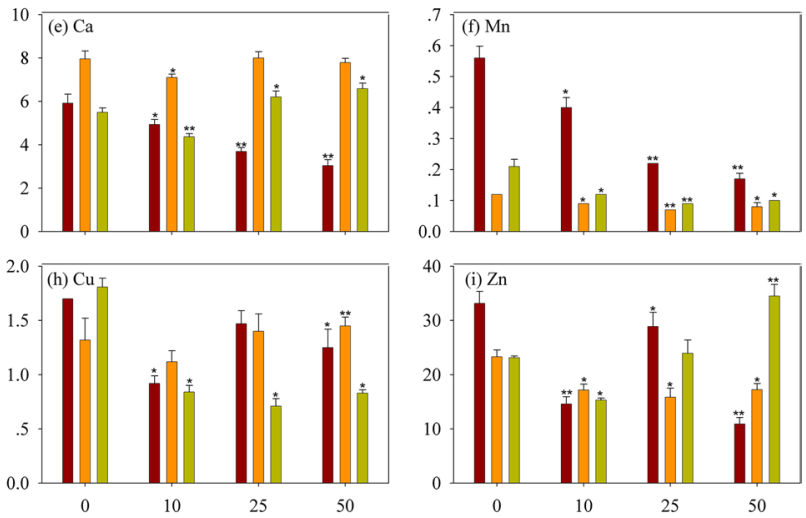

$\mathrm{AlCl}_{3}$ concentration $\left(\mathrm{mmol} \mathrm{L}^{-1}\right)$

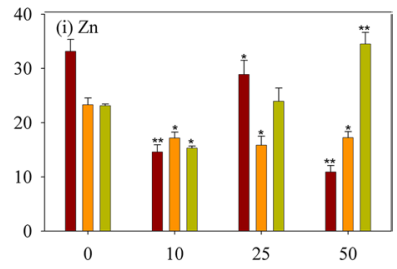

Table 1 The enrichment factors $(\mathrm{EF})$ of $\mathrm{Al}$, the ratio of $\mathrm{Na} / \mathrm{K}$ and $\mathrm{Al} / \mathrm{Ca}$, and the translocation factors (TF) of metal element in $B$. sexangula seedlings under long term (60 days) of $\mathrm{AlCl}_{3}$ treatment

\begin{tabular}{|c|c|c|c|c|c|c|c|c|c|c|c|c|c|c|c|c|c|c|}
\hline \multirow{2}{*}{$\begin{array}{l}\text { Al treatment } \\
\left(\mathrm{mmol} \mathrm{L}^{-1}\right)\end{array}$} & \multicolumn{3}{|l|}{ EF } & \multicolumn{3}{|c|}{$\mathrm{Na} / \mathrm{K}$} & \multicolumn{3}{|c|}{$\mathrm{Al} / \mathrm{Ca}$} & \multicolumn{9}{|l|}{ TF } \\
\hline & Leaf & Stem & Root & Leaf & Stem & Root & Leaf & Stem & Root & $\mathrm{Al}$ & $\mathrm{Na}$ & $\mathrm{K}$ & $\mathrm{Mg}$ & $\mathrm{Ca}$ & $\mathrm{Mn}$ & $\mathrm{Fe}$ & $\mathrm{Cu}$ & $\mathrm{Zn}$ \\
\hline 0 & & & & 1.32 & 0.98 & 1.21 & 0.07 & 0.05 & 0.09 & 1.58 & 1.87 & 1.97 & 1.44 & 2.52 & 3.23 & 2.31 & 1.67 & 2.44 \\
\hline 10 & 4.27 & 2.92 & 12.28 & 1.20 & 1.03 & 0.91 & 0.12 & 0.05 & 0.38 & 0.59 & 1.56 & 1.28 & 1.48 & 2.76 & 4.08 & 0.95 & 2.43 & 2.07 \\
\hline 25 & 0.24 & 0.15 & 0.56 & 1.32 & 1.37 & 1.51 & 0.22 & 0.06 & 0.30 & 0.70 & 1.38 & 1.56 & 1.67 & 1.88 & 3.22 & 0.98 & 4.04 & 1.87 \\
\hline 50 & 0.17 & 0.09 & 0.36 & 1.20 & 0.83 & 1.58 & 0.37 & 0.08 & 0.36 & 0.74 & 1.38 & 2.25 & 1.76 & 1.64 & 2.50 & 2.64 & 3.25 & 0.82 \\
\hline
\end{tabular}


under other treatments were below the level of 1 . For the ratio of $\mathrm{Na} / \mathrm{K}$, the lowest value was observed in the root after being treated with $10 \mathrm{mmol} \mathrm{L}^{-1} \mathrm{AlCl}_{3}$ (Table 1), and $\mathrm{Na} / \mathrm{K}$ was significantly increased with increasing $\mathrm{AlCl}_{3}$ concentrations in substrates. And similar result was also observed for the ratio of $\mathrm{Al} / \mathrm{Ca}$ (Table 1).

The TFs were defined as the ratio of the metal elements in the aboveground tissue (leaf and stem) to those in the underground tissue (root). The TF values of metal elements are presented in Fig. 7 and Table 1. Compared with the control, the $\mathrm{TF}$ values of $\mathrm{Al}$ were less than 1 under all $\mathrm{AlCl}_{3}$ treatments (Fig. 7a and Table 1). The TF values of essential metals in mangrove seedlings were differently affected by $\mathrm{AlCl}_{3}$ concentrations in the experimental media (Fig. 7b-i). For the essential metal elements of $\mathrm{Na}, \mathrm{K}, \mathrm{Mg}, \mathrm{Ca}, \mathrm{Mn}$ (Fig. 7b-f), and $\mathrm{Cu}$ (Fig. $7 \mathrm{~h}$ ), the TF values were often higher than 1 , and $\mathrm{Mg}$ was the most translocated macro-nutrient that increased with the increasing $\mathrm{AlCl}_{3}$ concentrations (TF: 1.44-1.76). The TF values of Na (Fig. 7b), Ca (Fig. 7e), Mn (Fig. 7f), and $\mathrm{Zn}$ (Fig. 7i) were significantly decreased under $\mathrm{AlCl}_{3}$ treatments, particularly under a hyper $\mathrm{AlCl}_{3}$ concentration of $50 \mathrm{~mol} \mathrm{~L}^{-1}$. Notably, $\mathrm{Mn}$ and $\mathrm{Cu}$ were the most translocated trace metals (TF: $2.50-4.08$ and 1.67-4.04, respectively).

\section{Discussion}

\section{Aluminum stress tolerance in $K$. obovata and $B$. sexangula seedlings}

K. obovata and B. sexangula differed in their ability to grow at varying $\mathrm{AlCl}_{3}$ concentrations. The two mangrove seedlings showed remarkable tolerance to hypo and hyper $\mathrm{AlCl}_{3}$ conditions, respectively. K. obovata survived in tested $\mathrm{AlCl}_{3}$ concentrations of $0.0625-10 \mathrm{mmol} \mathrm{L}^{-1}$, whereas that of $B$. sexangula was even higher with $\mathrm{AlCl}_{3}$ concentrations of $10-50 \mathrm{mmol} \mathrm{L}^{-1}$. In addition, $K$. obovata and B. sexangula seedlings had, respectively, high tolerance potential of 10 and $50 \mathrm{mmol} \mathrm{L}^{-1} \mathrm{AlCl}_{3}$, suggesting that $B$. sexangula had a higher Al tolerance ability. Related studies have shown that the Al-resistance ability of plants depends on their species (Boscolo et al. 2003; Darkó et al. 2004). The tolerance of high concentrations of $\mathrm{Al}$ has been examined in some plants; for instance, soybean (Glycine max (L.) Merr.) seedlings can normally grow under $10-75 \mu \mathrm{mol} \mathrm{L}{ }^{-1} \mathrm{Al}$ stress (Cakmak and Horst 1991), tea plant (Camellia sinensis (L.) O. Ktze.) can tolerate $0.5-4.0 \mathrm{mmol} \mathrm{L}^{-1} \mathrm{Al}$ treatments (Morita et al. 2008), and woody plants such as Cryptomeria japonica (L. f.) D. Don, Pinus thunbergii Parl., and Populus tremula (L.) native to acid soils have evolved various strategies to overcome Al stress (Brunner and Sperisen 2013). K. obovata and $B$. sexangula are both salt exclusion mangrove species belonging to Rhizophoraceae Pers., which is associated with heavy metal regulation (MacFarlane et al. 2007; Zhang et al.
Fig. 7 The translocation factor (TF) of $\mathrm{Al}(\mathbf{a}), \mathrm{Na}(\mathbf{b}), \mathrm{K}(\mathbf{c})$, $\mathrm{Mg}(\mathbf{d}), \mathrm{Ca}(\mathbf{e}), \mathrm{Mn}(\mathbf{f}), \mathrm{Fe}$ (g), $\mathrm{Cu}(\mathbf{h})$, and $\mathrm{Zn}(\mathbf{i})$ in $B$. sexangula seedlings under a long-term (60 days) treatment with $0-50.0 \mathrm{mmol} \mathrm{L}^{-1} \mathrm{AlCl}_{3}$. Values are mean $\pm \mathrm{SD}$
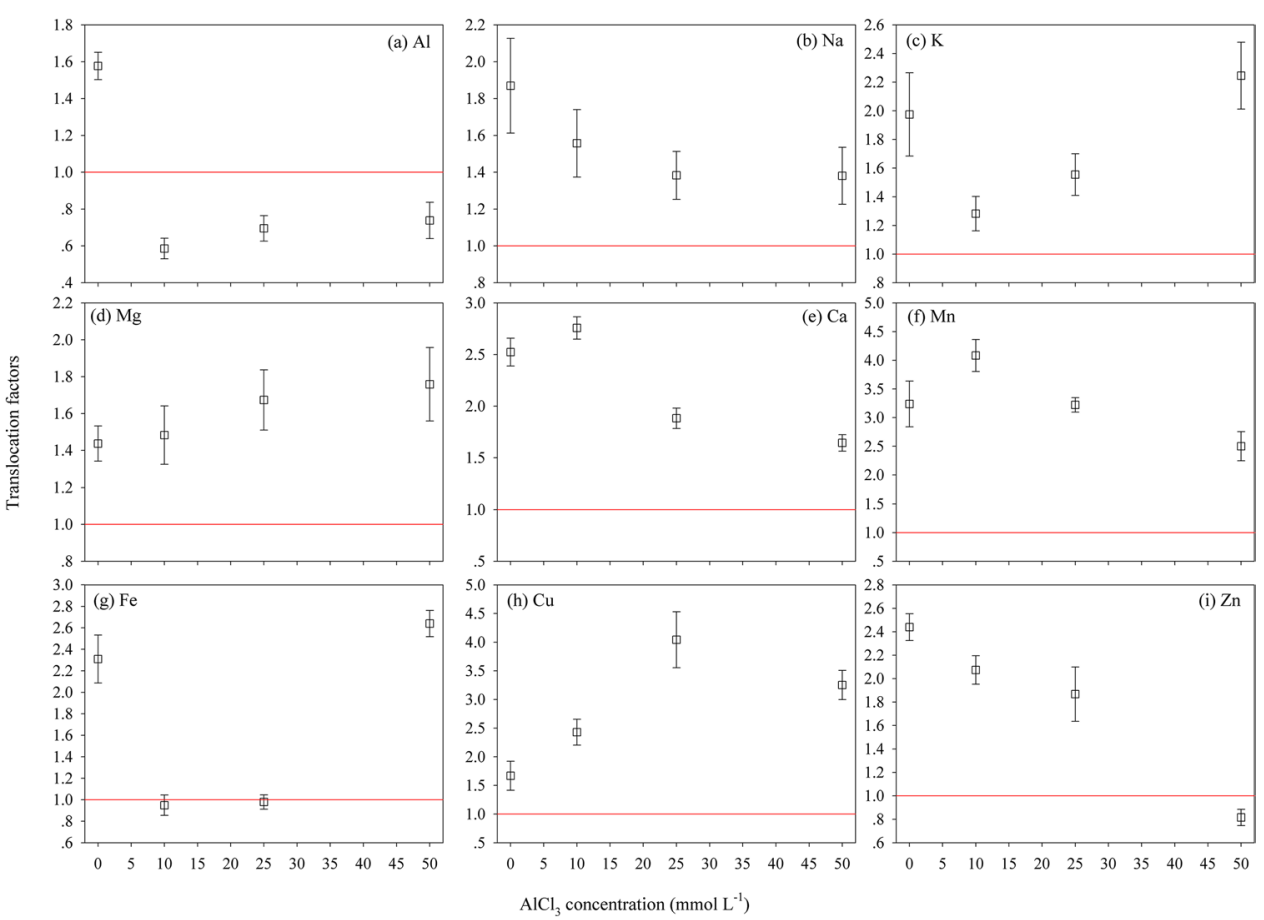
2007; Dai et al. 2017). We proposed that mangroves can tolerate high concentrations of $\mathrm{AlCl}_{3}$ stress and hold more effective resistance to $\mathrm{Al}$ than other reported plants.

The effect of Al toxicity in plants is widely known to inhibit plant growth and root elongation under acidic conditions (Marschner 1991; Barceló and Poschenrieder 2002; Bertrand et al. 2002; Kochian et al. 2004; Sivaguru et al. 2003; Tamás et al. 2003; Fukuda et al. 2007). In our study, hypo and hyper $\mathrm{AlCl}_{3}$ adversely affected the root elongation and seedling growth in mangroves. Concerning the behavior of hypo $\mathrm{AlCl}_{3}\left(0.0625-1.0 \mathrm{mmol} \mathrm{L}^{-1}\right)$ for $K$. obovata, the root elongation was inhibited compared with that of control (Fig. 1a). It was noticed that the seedling height of B. sexangula was significantly decreased in high $\mathrm{AlCl}_{3}$ conditions $\left(25-50 \mathrm{mmol} \mathrm{L}^{-1}\right)$ than in low ones $\left(10 \mathrm{mmol} \mathrm{L}^{-1}\right)$ (Fig. $\left.1 \mathrm{~b}\right)$. Rapid inhibition of root elongation of plant is the earliest visible symptom of Al toxicity (Kochian 1995; Sivaguru and Horst 1998; Yang et al. 2008; Panda et al. 2009; Kochian et al. 2015), which could occur within 1-2 h after exposure to Al (Ryan et al. 1993) and cause root stunting. These symptoms have been observed in $K$. obovata and B. sexangula seedlings: the root elongation was distinctly restrained, and the root tip was seriously damaged by $\mathrm{AlCl}_{3}$ stress.

\section{Effect of aluminum on lipid peroxidation and osmotic stress in K. obovata and B. sexangula seedlings}

Metal stress generally increases oxidative damage and lipid peroxidation, thus promoting the accumulation of MDA in plants (Chaoui et al. 1997; Ozturk et al. 2010; Nahar et al. 2016; Dai et al. 2017). In this study, lipid peroxidation level (expressed as MDA content), as oxidative stress parameters, was significantly affected by $\mathrm{AlCl}_{3}$ in mangrove seedlings. When compared with the control, the contents of MDA were significantly increased in $K$. obovata seedlings under short-term $(168 \mathrm{~h}) \mathrm{AlCl}_{3}$ treatments at 25 and $100 \mathrm{mmol} \mathrm{L}^{-1}$ (Fig. 2a), and in B. sexangula seedlings under a long-term (60 days) $\mathrm{AlCl}_{3}$ treatment at $50 \mathrm{mmol} \mathrm{L}^{-1}$ (Fig. 3a). These experimental results support that $K$. obovata is damaged rapidly by ROS and it can be classified as a more stresssusceptible species. Although $B$. sexangula has a relatively high endogenous MDA content (control), MDA content was clearly increased in the both leaf and root after a long-term $\mathrm{AlCl}_{3}$ treatment at $50 \mathrm{mmol} \mathrm{L}^{-1}$ (Fig. 3a), suggesting that a high degree of lipid peroxidation occurred in $B$. sexangula seedlings, which can be considered as a more stress-tolerant mangrove species that could better avoid oxidative damage.

Proline accumulation under metal stress has been recognized as potential indicator of tolerance; the high levels of free proline accumulated in plants reflect their response to osmotic stress (Iyer and Caplan 1998; Ashraf and Foolad 2007; Ahmad et al. 2015). Increased production of proline directly indicates its protective role in scavenging free radical, stabilizing subcellular structure, and maintaining redox imbalance of the cell (Ahmad et al. 2015; Zouari et al. 2016). In this study, the contents of proline were significantly affected by $\mathrm{AlCl}_{3}$ in the two mangrove seedlings. For short-term $\mathrm{AlCl}_{3}$ treatments, $K$. obovata produced more proline with the elongation of the treatment time (Fig. 2b), suggesting the osmotic stress in $K$. obovata seedlings rapidly responded to $\mathrm{AlCl}_{3}$ stress. In contrast to $K$. obovata, the content of proline in $B$. sexangula seedlings was continuously maintained at a high level within 60 days (Fig. 3b), which was increased by 7.2-14.4 and 10.7-30.1 times in the leaf and root, respectively. These results explained well that $B$. sexangula has stronger and more effective resistance mechanisms than $K$. obovata. The accumulation of proline has been shown to positively correlate with the resistance of plants (Sharma and Dietz 2006). In the present study, with the increase of $\mathrm{AlCl}_{3}$ concentration, the content of proline was increased in the two mangrove seedlings, which may be attributed to the low external osmotic potential induced by Al stress. In order to avoid seepage damage, plant cells actively accumulate soluble substances, such as proline, to avoid damage caused by water loss (Zouari et al. 2016). Additionally, proline can combine with free metal ions such as $\mathrm{Al}^{3+}$ and form nontoxic $\mathrm{Al}$-proline complexes, which can reduce $\mathrm{Al}$ toxicity to the active sites of enzymes (Sharma et al. 1998).

\section{Effect of aluminum on antioxidant enzyme activities in $K$. obovata and $B$. sexangula seedlings}

Related studies have demonstrated that $\mathrm{Al}$ can induce severe oxidative stress in organisms, due to the formation of free radicals and disintegration of ROS metabolism by Al toxicity (Boscolo et al. 2003; Tamás et al. 2003; Darkó et al. 2004; Liu et al. 2008; de Sousa et al. 2016; Ali 2017; Awad et al. 2019; Chandra et al. 2020; Chandra and Keshavkant 2021). In response to $\mathrm{Al}$ stress, antioxidant enzymes, including SOD, CAT, POD, and APX, are correlated with the ability to scavenge ROS formed under stress conditions (Cakmak and Horst 1991; Tamás et al. 2003; Nahar et al. 2016; Al Mahmud et al. 2019; Devi et al. 2020). In the present study, both the two mangrove seedlings revealed significant changes in SOD, CAT, and POD activities throughout the entire range of $\mathrm{AlCl}_{3}$ concentrations. $K$. obovata and B. sexangula mostly depend on SOD as the first line of defense; SOD activity is directly related to stress by converting $\mathrm{O}_{2}^{-}$that drives cell damage to $\mathrm{H}_{2} \mathrm{O}_{2}$ (Hasanuzzaman et al. 2020). Then CAT and POD, as well as APX in chloroplasts, subsequently scavenge the generated $\mathrm{H}_{2} \mathrm{O}_{2}$ via a two-electron transfer producing $\mathrm{O}_{2}$ and $\mathrm{H}_{2} \mathrm{O}$, thus avoiding the production of $\mathrm{OH}^{-}(\mathrm{Cakmak}$ and 
Marschner 1992; Vranová et al. 2002; Nahar et al. 2016; Al Mahmud et al. 2019; Devi et al. 2020).

Evidently, the antioxidant enzyme activities are differently regulated by the treatment time and $\mathrm{AlCl}_{3}$ concentration between mangrove species. It is likely that, SOD activity in $K$. obovata increased for dismutation of superoxide ion and the generated $\mathrm{H}_{2} \mathrm{O}_{2}$ was subsequently degraded by CAT and POD within $168 \mathrm{~h}$ (Fig. 4a-c). Whereas the activity of APX and SOD, respectively, increased in the leaf and root of $B$. sexangula seedlings, the generated $\mathrm{H}_{2} \mathrm{O}_{2}$ was subsequently degraded by POD after exposure to $\mathrm{AlCl}_{3}$ treatments at extreme concentrations within 60 days (Fig. 5a-c). Increases in antioxidant enzyme activities are known as the primary prevention of stress damage, and elevated activities of SOD and POD might result from the de novo synthesis and expression of enzymatic proteins induced by $\mathrm{Al}$ stress (Cakmak and Horst 1991; Devi et al. 2003; Sivaguru et al. 2003). Additionally, the function of POD has been widely accepted as a potential biomarker for sub-lethal metal toxicity in plants (Radotić et al. 2000). High levels of POD activity observed in $K$. obovata and $B$. sexangula seedlings suggested a better intrinsic defense to resist Al-induced oxidative damage in mangroves. Notably, APX is an important enzyme for decomposing $\mathrm{H}_{2} \mathrm{O}_{2}$ and $\mathrm{O}_{2}{ }^{-}$through the ascorbic acid-glutathione cycle in the chloroplast, and the increase in APX activity can be considered the defensive response to ROS (Cakmak and Marschner 1992). In the leaf of B. sexangula seedlings, APX activity increased and compensated for the decline of CAT activity (Fig. 5 a and d), suggesting that APX is involved in the degradation of $\mathrm{H}_{2} \mathrm{O}_{2}$ generated by $\mathrm{Al}$ stress.

\section{Effect of aluminum on metal accumulation and translocation in B. sexangula seedlings}

From the study of long-term (60 days) $\mathrm{AlCl}_{3}$ treatments on $B$. sexangula seedlings, the order of $\mathrm{Al}$ accumulation was root $>$ leaf $>$ stem (Fig. 6a and Table 1), and the uptake ability of $\mathrm{Al}$ with the highest $\mathrm{EF}$ value was observed in the root (Table 1), suggesting that root is the primarily important tissue of mangrove seedlings for $\mathrm{Al}$ deposition. The varying $\mathrm{EFs}$ of $\mathrm{Al}$ among tissues of $B$. sexangula seedlings after being treated with different concentrations of $\mathrm{AlCl}_{3}$ (Fig. 6a and Table 1) also indicated that $B$. sexangula differed in its absorption ability and accumulation response to different levels of $\mathrm{Al}$ stress. The $\mathrm{TF}$ values of $\mathrm{Al}$ were less than 1 under all $\mathrm{AlCl}_{3}$ treatments (Fig. 7a and Table 1), suggesting that the root can accumulate $\mathrm{Al}$ and limit its translocation to the leaf and stem to prevent $\mathrm{Al}$ toxicity.

Macro metal elements such as $\mathrm{Na}, \mathrm{K}$, and $\mathrm{Mg}$ are essential for the mangroves (Reef et al. 2010; Alongi 2018). Essential macro-elements like Na showed hyper-accumulation in the root under all $\mathrm{AlCl}_{3}$ treatments, being highest at
$25 \mathrm{mmol} \mathrm{L}^{-1} \mathrm{AlCl}_{3}$ (Fig. 6b). The distribution patterns of $\mathrm{Na}$ and $\mathrm{K}$ (Fig. $6 \mathrm{~b}$ and c) indicated that the root is the major tissue for the accumulation of these two metals. The ratio of $\mathrm{Na} / \mathrm{K}$ increased with the increasing $\mathrm{AlCl}_{3}$ concentrations in substrates (Table 1), suggesting the distinctly selective absorption of $\mathrm{Na}$ by the root and upward transport to the leaf. Conversely, the accumulation of $\mathrm{Mg}$ in the root was inhibited under $10-25 \mathrm{mmol} \mathrm{L}^{-1} \mathrm{AlCl}_{3}$ treatment (Fig. 6d), whereas the increased TF values of $\mathrm{Mg}$ (1.44-1.76) under $\mathrm{AlCl}_{3}$ treatment suggested that its translocation from the root to the aboveground tissues is efficient. These results suggested that the root is a very sensitive tissue that is affected by $\mathrm{AlCl}_{3}$ stress, whereas $\mathrm{Al}$ has weak impact on the transport of $\mathrm{Na}, \mathrm{K}$, and $\mathrm{Mg}$ in B. sexangula seedlings. We proposed that $B$. sexangula seedlings might hold a positive adaptation mechanism to $\mathrm{Al}$ stress, while stable levels of $\mathrm{Na}, \mathrm{K}$, and $\mathrm{Mg}$ in the leaf could benefit to maintain their normal metabolic processes, such as photosynthesis and respiration.

Calcium plays an important role in maintaining the stability of cell wall and membrane, and regulating the balance of ions and antioxidant enzymes (Cakmak and Horst 1991). Related studies have proposed that interactions between $\mathrm{Al}$ and $\mathrm{Ca}$ are probably the most important factors affecting $\mathrm{Ca}$ uptake and transport in plants. $\mathrm{Al}$ stress could disturb the absorption balance of calcium cation $\left(\mathrm{Ca}^{2+}\right)$ in plant cells, which further induced the generation of superoxide (Huang et al. 1992; Kawano et al. 2004). In the present study, the increase in $\mathrm{Ca}$ accumulation in the root might be attributed to an important mechanism in which seedlings employ the aggravating absorption of $\mathrm{Ca}$ in the root to relieve $\mathrm{Al}$ toxicity. However, the ratio of $\mathrm{Al} / \mathrm{Ca}$ was increased with the increasing $\mathrm{AlCl}_{3}$ concentration in the substrate (Table 1), suggesting that the effect of $\mathrm{Ca}$ on the suppression of $\mathrm{Al}$ toxicity might be restrained by high concentrations of $\mathrm{AlCl}_{3}$.

The uptake of micronutrients is primarily controlled by plant metabolic requirements, resulting in variable metal accumulations in different mangrove tissues. It is well known that $\mathrm{Mn}$ and $\mathrm{Fe}$ are essential nutritional elements for plant growth, particularly as an electron carrier in metabolism, protein synthesis, photosynthesis, chloroplast development, and antioxidant enzyme activities (Bertrand et al. 2002; Bose et al. 2014; Hasanuzzaman et al. 2020). Lack of $\mathrm{Mn}$ or $\mathrm{Fe}$ would cause protein reduction in the reaction center of photosynthetic system II (Green et al. 1991). Our results suggested that $\mathrm{Al}$ stress inhibited the absorption and transport of $\mathrm{Mn}$ and $\mathrm{Fe}$ in B. sexangula seedlings (Fig. $6 \mathrm{f}$ and g), which might further impact the physiological and biochemical processes that regulate functional enzyme activities. As an essential trace metal element for plants, $\mathrm{Cu}$ is closely involved in chlorophyll formation, as well as synthesis of proteins (Uriu-Adams and Keen 2005). Notably, in this study, the seedling curled leaf with brown lesions and the black root tips, suggesting that the accumulation and 
transport of $\mathrm{Cu}$ have been inhibited by $\mathrm{Al}$ stress. $\mathrm{Zn}$ is an essential catalytic component of over 300 enzymes, which could protect the sulfhydryl groups of enzymes against free radical attack, and it acts as an antagonist against redoxactive transition metals including $\mathrm{Fe}$ and $\mathrm{Cu}$ (Frassinetti et al. 2006). The increase in $\mathrm{Zn}$ in the root under hyper $\mathrm{AlCl}_{3}$ conditions (Fig. 6i) suggested its positive response to $\mathrm{Al}$ stress, compared to the opposite accumulation patterns of $\mathrm{Fe}$ and $\mathrm{Cu}$ in roots.

Mangrove plants accumulate metal micronutrients in the aboveground tissues (stem and leaf) because some metals are required for their growth and survival (Huang et al. 2020). For the essential metal elements of $\mathrm{Na}, \mathrm{K}, \mathrm{Mg}, \mathrm{Ca}, \mathrm{Mn}$, and $\mathrm{Cu}$, their TF values were often higher than 1 (Table 1), suggesting that the translocation of these metals from the root to the aboveground tissues is efficient. Conversely, the TF value of $\mathrm{Zn}$ was less than 1 under $50 \mathrm{mmol} \mathrm{L}^{-1} \mathrm{AlCl}_{3}$ treatment (Table 1), indicating an inhibition of translocation of this micronutrient. Notably, the TF values of $\mathrm{Na}, \mathrm{Ca}, \mathrm{Mn}$, and $\mathrm{Zn}$ were significantly decreased with the increasing $\mathrm{AlCl}_{3}$ concentration in the substrate (Fig. $7 \mathrm{~b}$, e, f, and i), particularly under hyper $\mathrm{AlCl}_{3}$ of $50 \mathrm{mmol} \mathrm{L}^{-1}$, suggesting that the translocation of these elements is inhibited by Al stress. In this study, $\mathrm{Mn}$ and $\mathrm{Cu}$ are the most translocated trace metals in mangrove issues, which are expected to play important roles in overall plant physiology (e.g., photosynthesis, chloroplast development, and sustenance of metabolism) (Reef et al. 2010; Bose et al. 2014; Alongi 2018; Hasanuzzaman et al. 2020; Huang et al. 2020). The differences between TFs of trace metals in mangroves may not necessarily be linked to the translocation of elements (Huang et al. 2020). B. sexangula was shown to have the highest TF values of $\mathrm{Cu}$ (up to 4.08) and Mn (up to 4.04), indicating that the translocation of these metals from the root to the shoot of this species efficiently occurs under Al toxicity. Typically, mangroves exhibit high TF values of essential elements such as Mn and $\mathrm{Cu}$ (MacFarlane et al. 2007).

These results highlight that the accumulation and translocation of metal elements are mainly inhibited in mangrove seedlings, in response to $\mathrm{AlCl}_{3}$ stress. To some extent, the tolerance of mangroves to heavy metals depends on the elimination and adjustment of heavy metals and the restriction of heavy metal translocation from the underground to aboveground tissues (Wang et al. 2016). In this study, although the accumulation and translocation of eight essential metal elements are differently affected by $\mathrm{Al}$ stress, the root is the most sensitive tissue for metal enrichment. The plants that have a certain degree of tolerance to polluted surroundings usually store heavy metals in the vacuole of the root cortex tissue or cell wall, so they can reduce heavy metal concentrations in the aboveground tissues (Zhao et al. 2015). Furthermore, metal transfer in a root-stem-leaf order can be affected by leaf transpiration; transpiration acts as a controller in Al transport (Liu et al. 2016), which has been confirmed in several plants (Van der Vliet et al. 2007; Liu et al. 2010).

\section{Conclusions}

This work demonstrates that the mangroves $K$. obovata and B. sexangula can adapt to high levels of $\mathrm{AlCl}_{3}$ in acid conditions, with the tolerance to $\mathrm{Al}$ toxicity reaching a maximum concentration of 10 and $50 \mathrm{mmol} \mathrm{L}^{-1}$, respectively. Mangrove seedlings can grow and survive in high $\mathrm{Al}$ environments, but with reduced root length and seedling weight as the negative response to $\mathrm{Al}$ stress. Under $\mathrm{AlCl}_{3}$ treatments, two features are evident in this study: (1) $\mathrm{Al}$ stress increased lipid peroxidation (expressed as MDA content) and osmotic pressure (indicated in proline content) levels, suggesting ROS molecules destroy membrane lipids. Antioxidant enzymes were activated under hyper $\mathrm{AlCl}_{3}$ conditions; changes in enzyme activities indicate that oxidative stress is induced. Synergistic effects of SOD, CAT, POD, and/or APX could maintain the metabolic balance of active oxygen in $K$. obovata and B. sexangula seedlings within a certain time. As a general tolerance mechanism, the growth behavior of mangrove seedlings under $\mathrm{Al}$ stress is correlated with the elevated activities of protective enzymes. (2) In response to Al stress, B. sexangula seedlings primarily retained $\mathrm{Al}$ in the root, and the low TF values of Al in the aboveground tissues (stem and leaf) support that low mobility is used as a strategy to avoid excessive uptake of metals into seedling bodies. The different tolerant abilities of mangrove species provide valuable information for mangrove rehabilitation in acid conditions and their adaptation to Al stress. To provide a better insight into the effect of geochemical conditions on the survival and growth of mangroves, further field studies should be extended to monitor the responses of mangrove species to continuously long exposure to $\mathrm{Al}$.

Acknowledgements Authors would like to thank all colleagues from Key Laboratory of the Coastal and Wetland Ecosystem for their fieldwork and trial support.

Author contribution Shengchang Yang conceived and designed the experiments. Li Ma performed the field sampling, laboratory experiments and analyzed the data. Li Ma and Shengchang Yang wrote the paper. All authors contributed to the interpretation of results and critical revision.

Funding This work was funded by the National Natural Science Foundation of China (Grant No. 30972334), the National key research and development program of China (Grant No. 2017YFC0506103), the City Basic Research Program of Chengde, China (Grant No. 202102A059), and the Construction and Technology Special Science Projects of the National Sustainable Development Agenda Innovation Demonstration Zone (Grant No. 202104F003 and No. 202104F028). 
Data availability All data can be accessed in the form of Excel spreadsheets via the corresponding author.

\section{Declarations}

Ethical approval Not applicable.

Consent to participate Not applicable.

Consent to publish Not applicable.

Competing interest The authors declare no competing interests.

Open Access This article is licensed under a Creative Commons Attribution 4.0 International License, which permits use, sharing, adaptation, distribution and reproduction in any medium or format, as long as you give appropriate credit to the original author(s) and the source, provide a link to the Creative Commons licence, and indicate if changes were made. The images or other third party material in this article are included in the article's Creative Commons licence, unless indicated otherwise in a credit line to the material. If material is not included in the article's Creative Commons licence and your intended use is not permitted by statutory regulation or exceeds the permitted use, you will need to obtain permission directly from the copyright holder. To view a copy of this licence, visit http://creativecommons.org/licenses/by/4.0/.

\section{References}

Ábrahám E, Hourton-Cabassa C, Erdei L, Szabados L (2010) Methods for determination of proline in plants. In: Sunkar R (ed) Plant Stress Tolerance. Methods in Molecular Biology (Methods and Protocols). Humana Press. 639:317-331. https://doi.org/10.1007/ 978-1-60761-702-0_20

Agoramoorthy G, Chen FA, Hsu MJ (2008) Threat of heavy metal pollution in halophytic and mangrove plants of Tamil Nadu, India. Environ Pollut 155(2):320-326. https://doi.org/10.1016/j.envpol. 2007.11.011

Ahmad P, Sarwat M, Bhat NA, Wani MR, Kazi AG, Tran LSP (2015) Alleviation of cadmium toxicity in Brassica juncea L. (Czern. \& Coss.) by calcium application involves various physiological and biochemical strategies. PLoS ONE 10(1):e0114571. https://doi. org/10.1371/journal.pone.0114571

Al Mahmud J, Bhuyan MHMB, Anee TI, Nahar K, Fujita M, Hasanuzzaman M (2019) Reactive oxygen species metabolism and antioxidant defense in plants under metal/metalloid stress. In: Hasanuzzaman M, Hakeem K, Nahar K, Alharby H (eds) Plant Abiotic Stress Tolerance. Springer, Cham, pp 221-257. https:// doi.org/10.1007/978-3-030-06118-0_10

Ali B (2017) Salicylic acid induced antioxidant system enhances the tolerance to aluminum in mung bean (Vigna radiata L. Wilczek) plants. Ind J Plant Physiol 22:178-189. https://doi.org/10.1007/ s40502-017-0292-1

Alongi DM (2018) Impact of global change on nutrient dynamics in mangrove forests. Forests 9:596. https://doi.org/10.3390/f9100 596

Alongi DM (2005) Mangrove-Microbe-Soil Relations. In: Kristensen E, Haese RR, Kostka JE (eds) Interactions Between Macro and Microorganisms in Marine Sediments, Volume 60. Coastal Estuarine Stud., pp 85-103, AGU, Washington, D. C. ISBN: 9781118665442. https://doi.org/10.1029/CE060
Ashraf M, Foolad M (2007) Roles of glycine betaine and proline in improving plant abiotic stress resistance. Environ Exp Bot 59(2):206-216. https://doi.org/10.1016/j.envexpbot.2005.12.006

Awad KM, Salih AM, Khalaf Y, Suhim AA, Abass MH (2019) Phytotoxic and genotoxic effect of aluminum to date palm (Phoenix dactylifera L.) in vitro cultures. J.G.E.B. 17:7. https://doi.org/10. 1186/s43141-019-0007-2.

Ball MC, Cochrane MJ, Rawson HM (1997) Growth and water use of the mangroves, Rhizophora apiculata and R stylosa, in response to salinity and humidity under ambient and elevated concentrations of atmospheric CO2. Plant Cell Environ 20(9):1158-1166. https://doi.org/10.1046/j.1365-3040.1997.d01-144.x

Barceló J, Poschenrieder C (2002) Fast root growth responses, root exudates and internal detoxification as clues to the mechanisms of aluminium toxicity and resistance: a review. Environ Exp Bot 48(1):75-92. https://doi.org/10.1016/S0098-8472(02)00013-8

Basyuni M, Keliat DA, Lubis MU, Manalu NB, Syuhada A, Wati R, Yunasfi (2018) Growth and root development of four mangrove seedlings under varying salinity. IOP Conf. Ser.: Earth Environ. Sci. 130:012027. https://doi.org/10.1088/1755-1315/130/1/ 012027

Bertrand M, Guary J, Schoefs B (2002) How plants adapt their physiology to an excess of metals. In: Pessarakli M (ed) Handbook of Plant and Crop Physiology. Marcel Dekker, New York, pp $751-762$

Blake L (2005) Acid Rain and Soil Acidification-Science Direct. In: Hillel D (ed) Encyclopedia of Soils in the Environment. pp 1-11.

Bleam WF (2012) Acid-Base Chemistry. In: Soil and Environmental Chemistry. pp 257-319. https://doi.org/10.1016/ C2011-0-05612-0

Boscolo PRS, Menossi M, Jorge RA (2003) Aluminum-induced oxidative stress in maize. Phytochemistry 62(2):181-189. https://doi. org/10.1016/S0031-9422(02)00491-0

Bose J, Rodrigo-Moreno A, Shabala S (2014) ROS homeostasis in halophytes in the context of salinity stress tolerance. J Exp Bot 65(5):1241-1257. https://doi.org/10.1093/jxb/ert430

Bradford MM (1976) A rapid and sensitive method for the quantification of microgram quantities of protein utilizing the principle of protein-dye binding. Anal Biochem 72(1-2):248-254. https:// doi.org/10.1016/0003-2697(76)90527-3

Brunner I, Sperisen C (2013) Aluminum exclusion and aluminum tolerance in woody plants. Front Plant Sci 4:172. https://doi.org/10. 3389/fpls.2013.00172

Burchett MD, Field CD, Pulkownik A (1984) Salinity, growth and root respiration in the grey mangrove, Avicennia marina. Physiol Plant 60(2):113-118. https://doi.org/10.1111/j.1399-3054.1984. tb04549.x

Cai W-J, Hu X, Huang W-J, Murrell MC, Lehrter JC, Lohrenz SE, Chou W-C, Zhai W, Hollibaugh JT, Wang Y, Zhao P, Guo X, Gundersen K, Dai M, Gong G-C (2011) Acidification of subsurface coastal waters enhanced by eutrophication. Nat Geosci 4:766-770. https://doi.org/10.1038/ngeo1297

Cakmak I, Horst WJ (1991) Effect of aluminium on lipid peroxidation, superoxide dismutase, catalase and peroxidase activities in root tips of soybean (Glycine max). Physiol Plant 83(3):463-468. https://doi.org/10.1111/j.1399-3054.1991.tb00121.x

Cakmak I, Marschner H (1992) Magnesium deficiency and high light intensity enhance activities of superoxide dismutase, ascorbate peroxidase, and glutathione reductase in bean leaves. Plant Physiol 98(4):1222-1227. https://doi.org/10.1104/pp.98.4.122

Caregnato FF, Koller, CE, MacFarlane GR, Moreira JCF (2008) The glutathione antioxidant system as a biomarker suite for the assessment of heavy metal exposure and effect in the grey mangrove, Avicennia marina (Forsk.) Vierh. Mar Pollut Bull 56(6):1119-1127. https://doi.org/10.1016/j.marpolbul.2008.03. 019 
Chandra J, Parkhey S, Varghese D, Sershen VB, Keshavkant S (2020) Aluminium rhizotoxicity in Cicer arietinum. Russ. J. Plant Physiol. 67:945e952. https://doi.org/10.1134/S102144 3720050027.

Chandra J, Keshavkant S (2021) Mechanisms underlying the phytotoxicity and genotoxicity of aluminum and their alleviation strategies: a review. Chemosphere 278:130384. https://doi.org/ 10.1016/j.chemosphere.2021.130384

Chaoui A, Mazhoudi S, Ghorbal MH, El Ferjani E (1997) Cadmium and zinc induction of lipid peroxidation and effects on antioxidant enzyme activities in bean (Phaseolus vulgaris L.). Plant Sci 127(2):139-147. https://doi.org/10.1016/S0168-9452(97) 00115-5

Chen L, Wang W (2017) Ecophysiological responses of viviparous mangrove Rhizophora stylosa seedlings to simulated sea-level rise. J Coastal Res 33(6):1333-1340. https://doi.org/10.2112/ JCOASTRES-D-16-00131.1

Chen GC, Ye Y, Lu CY (2007) Changes of macro-benthic faunal community with stand age of rehabilitated Kandelia candel mangrove in Jiulongjiang Estuary, China. Ecol Eng 31(3):215-224. https:// doi.org/10.1016/j.ecoleng.2007.07.002

Chen L, Wang W, Zhang Y, Lin G (2009) Recent progresses in mangrove conservation, restoration and research in China. J Plant Ecol 2(2):45-54. https://doi.org/10.1093/jpe/rtp009

Chen L, Wang W, Li Q, Zhang Y, Yang S, Osland MJ, Huang J, Peng $\mathrm{C}$ (2017) Mangrove species' responses to winter air temperature extremes in China. Ecosphere 8(6):e01865. https://doi.org/10. $1002 /$ ecs 2.1865

Cook FJ, Hicks W, Gardner EA, Carlinà GD, Froggatt DW (2000) Export of acidity in drainage water from acid sulphate soils. Mar Pollut Bull 41(7-12):319-326. https://doi.org/10.1016/S0025326X(00)00138-7

Costa ES, Sá F, Gomes LEO, Silva CA, Lima AT, Lehrback BD, Neto RR (2020) Can severe drought periods increase metal concentrations in mangrove sediments? A case study in eastern Brazil Science of the Total Environment 748:142443. https://doi.org/ 10.1016/j.scitotenv.2020.142443

Dai M, Lu H, Liu W, Jia H, Hong H, Liu J, Yan C (2017) Phosphorus mediation of cadmium stress in two mangrove seedlings Avicennia marina and Kandelia obovata differing in cadmium accumulation. Ecotoxicol Environ Saf 139:272-279. https://doi.org/10. 1016/j.ecoenv.2017.01.017

Darkó É, Ambrus H, Éva SB, Fodor J, Bakos F, Barnabás B (2004) Aluminum toxicity, $\mathrm{Al}$ tolerance and oxidative stress in an Alsensitive wheat genotype and in Al-tolerant lines developed by in vitro microspore selection. Plant Sci 166(3):583-591. https:// doi.org/10.1016/j.plantsci.2003.10.023

Dazy M, Masfaraud J-F, Férard J-F (2009) Induction of oxidative stress biomarkers associated with heavy metal stress in Fontinalis antipyretica Hedw. Chemosphere 75(3):297-302. https://doi.org/10. 1016/j.chemosphere.2008.12.045

de Sousa A, AbdElgawad H, Han A, Teixeira J, Matos M, Fidalgo F (2016) Oxidative metabolism of rye (Secale cereale L.) after short term exposure to aluminum, uncovering the glutathioneascorbate redox network. Front Plant Sci 7:685. https://doi.org/ 10.3389/fpls.2016.00685

Devi SR, Yamamoto Y, Matsumoto H (2003) An intracellular mechanism of aluminum tolerance associated with high antioxidant status in cultured tobacco cells. J Inorg Biochem. 97:59e68. https:// doi.org/10.1016/S0162-0134(03)00182-X.

Devi SS, Saha B, Panda SK (2020) Differential Loss of ROS homeostasis and activation of anti oxidative defense response in tea cultivar due to $\mathrm{Al}$ toxicity in acidic soil. Curr Trends Biotechnol Pharm. 14:33e43. https://doi.org/10.5530/ctbp.2020.1.3.

Doney SC, Fabry VJ, Feely RA, Kleypas JA (2009) Ocean acidification: the other $\mathrm{CO}_{2}$ problem. Annu Rev Mar Sci 1:169-192. https://doi.org/10.1146/annurev.marine.010908.163834
Downton WJS (1982) Growth and osmotic relations of the mangrove Avicennia marina as influenced by salinity. Aust J Plant Physiol 9(5):519-528. https://doi.org/10.1071/PP9820519

Frassinetti S, Bronzetti G, Caltavuturo L, Cini M, Croce D (2006) The role of zinc in life: a review. J Environ Pathol Toxicol Oncol 25(3):597-610. https://doi.org/10.1615/JEnvironPatholToxico 1Oncol.v25.i3.40

Fukuda T, Saito A, Wasaki J, Shinano T, Osaki M (2007) Metabolic alterations proposed by proteome in rice roots grown under low $\mathrm{P}$ and high $\mathrm{Al}$ concentration under low pH. Plant Sci 172(6):11571165. https://doi.org/10.1016/j.plantsci.2007.02.020

Garcia-Limones C, Hervas A, Navas-Cortes JA, Jimenez-Diaz RM, Tena M (2002) Induction of an antioxidant enzyme system and other oxidative stress markers associated with compatible and incompatible interactions between chickpea (Cicer arietinum L.) and Fusarium oxysporum f. sp. ciceris. Physiol Mol Plant Path 61(6):325-337. https://doi.org/10.1006/pmpp.2003.0445

Garilli V, Rodolfo-Metalpa R, Scuderi D, Brusca L, Parrinello D, Rastrick SPS, Foggo A, Twitchett RJ, Hall-Spencer JM, Milazzo M (2015) Physiological advantages of dwarfing for life in high- $\mathrm{CO}_{2}$ oceans. Nat Clim Change 5:678-682. https://doi.org/10.1038/ nclimate 2616

Gossett DR, Millhollon EP, Lucas MC (1994) Antioxidant response to $\mathrm{NaCl}$ stress in salt tolerant and salt sensitive cultivars of cotton. Crop Sci 34(3):706-714. https://doi.org/10.2135/cropsci1994. 0011183X003400030020x

Green RM, Geider RJ, Falkowski PG (1991) Effect of iron-limitation on photosynthesis in a marine diatom. Limnol Oceanogr 36(8):1772-1782. https://doi.org/10.4319/lo.1991.36.8.1772

Hasanuzzaman M, Borhannuddin Bhuyan MHM, Zulfiqar F, Raza A, Mohsin SM, Al Mahmud J, Fujita M, Fotopoulos V (2020) Reactive Oxygen Species and Antioxidant Defense in Plants under Abiotic Stress: Revisiting the Crucial Role of a Universal Defense Regulator. Antioxidants 9(8):681. https://doi.org/10. 3390/antiox9080681

Hossain MD, Inafuku M, Iwasaki H, Taira N, Mostofa MG, Oku H (2017) Differential enzymatic defense mechanisms in leaves and roots of two true mangrove species under long-term salt stress. Aquat Bot 142:32-40. https://doi.org/10.1016/j.aquabot.2017. 06.004

Huang GY, Wang YS (2010) Physiological and biochemical responses in the leaves of two mangrove plant seedlings (Kandelia candel and Bruguiera gymnorrhiza) exposed to multiple heavy metals. J Hazard Mater 182(1-3):848-854. https://doi.org/10.1016/j.jhazm at.2010.06.121

Huang JW, Shaff JE, Grunes DL, Kochian LV (1992) Aluminum effects on calcium fluxes at the root apex of aluminum tolerant and aluminum sensitive wheat cultivars. Plant Physiol 98(1):230-237. https://doi.org/10.1104/pp.98.1.230

Huang X, Wang X, Li X, Yan Z, Sun Y (2020) Occurrence and transfer of heavy metals in sediments and plants of Aegiceras corniculatum community in the Qinzhou Bay, southwestern China. Acta Oceanol Sin 39:79-88. https://doi.org/10.1007/ s13131-020-1555-7

Isyrini R (2014) The Effects of Geochemical Conditions on the Establishment and Growth of Mangrove Seedlings in Acid Sulfate Soil Environments. Ph.D Thesis, School of Earth, Environmental and Biological Science, Science and Engineering Faculty, Queensland University of Technology.

Iyer S, Caplan A (1998) Products of proline catabolism can induce osmotically regulated genes in rice. Plant Physiol 116(1):203211. https://doi.org/10.1104/pp.116.1.203

Jones GB, Mercurio P, Olivier F (2000) Zinc in fish, crabs, oysters, and mangrove flora and fauna from Cleveland Bay. Mar Pollut Bull 41(7-12):345-352. https://doi.org/10.1016/S0025-326X(00) 00132-6 
Kawano T, Kadono T, Fumoto K, Lapeyrie F, Kuse M, Isobe M, Furuichi T, Muto S (2004) Aluminum as a specific inhibitor of plant TPC1 $\mathrm{Ca}^{2+}$ channels. Biochem Biophys Res Commun 324(1):40-45. https://doi.org/10.1016/j.bbrc.2004.09.015

Kochian LV (1995) Cellular mechanisms of aluminum toxicity and resistance in plants. Annu Rev Plant Physiol Plant Mol Biol 46:237-260. https://doi.org/10.1146/annurev.pp.46.060195. 001321

Kochian LV, Hoekenga OA, Pineros MA (2004) How do crop plants tolerate acid soils?-mechanisms of aluminum tolerance and phosphorous efficiency. Annu Rev Plant Biol 55:459-493. https://doi.org/10.1146/annurev.arplant.55.031903.141655

Kochian L, Piñeros M, Liu J, Magalhaes J (2015) Plant adaptation to acid soils: the molecular basis for crop aluminum resistance. Annu Rev Plant Biol 66:571-598. https://doi.org/10.1146/annur ev-arplant-043014-114822

Kombo MM, Bakari SS, Okada K, Fujimura H, Shinjo R, Tokuyama A (2005) Behaviors of Aluminum and DOC in waters of the Gesashi mangrove estuary, Okinawa (Japan). https://doi.org/10. 14862/geochemproc.52.0.138.0

Kwiatkowski L, Gaylord B, Hill T, Hosfelt J, Kroeker KJ, Nebuchina Y, Ninokawa A, Russell AD, Rivest EB, Sesboüé M, Caldeira K (2016) Nighttime dissolution in a temperate coastal ocean ecosystem increases under acidification. Sci Rep 6:22984. https:// doi.org/10.1038/srep22984

Le Quéré C, Moriarty R, Andrew RM, Peters GP, Ciais P, Friedlingstein P et al (2015) Global carbon budget 2014. Earth Syst Sci Data 7(1):47-85. https://doi.org/10.5194/essd-7-47-2015

Li T, Ye Y (2014) Dynamics of decomposition and nutrient release of leaf litter in Kandelia obovata mangrove forests with different ages in Jiulongjiang Estuary, China. Ecol Eng 73:454-460. https://doi.org/10.1016/j.ecoleng.2014.09.102

Liu Q, Yang JL, He LS, Li YY, Zheng SJ (2008) Effect of aluminum on cell wall, plasma membrane, antioxidants and root elongation in triticale. Biol Plantarum 52:87-92. https://doi.org/10.1007/ s10535-008-0014-7

Liu Y, Tam NF, Yang JX, Pi N, Wong MH, Ye ZH (2009) Mixed heavy metals tolerance and radial oxygen loss in mangrove seedlings. Mar Pollut Bull 58(12):1843-1849. https://doi.org/10.1016/j. marpolbul.2009.07.023

Liu X, Peng K, Wang A, Lian C, Shen Z (2010) Cadmium accumulation and distribution in populations of Phytolacca americana $\mathrm{L}$. and the role of transpiration. Chemosphere 78(9):1136-1141. https://doi.org/10.1016/j.chemosphere.2009.12.030

Liu H, Wang H, Ma Y, Wang H, Shi Y (2016) Role of transpiration and metabolism in translocation and accumulation of cadmium in tobacco plants (Nicotiana tabacum L.). Chemosphere 144:19601965. https://doi.org/10.1016/j.chemosphere.2015.10.093

Lu ZQ, Zheng WJ, Ma L (2012) Growth and physiological responses of mangrove Kandelia candel (L.) Druce (Rhizophoraceae) to naphthalene exposure. Vie Et Milieu 62(2):55-59

MacFarlane GR, Burchett MD (2000) Cellular distribution of copper, lead and zinc in the grey mangrove, Avicennia marina (Forsk.) Vierh. Aquat Bot 68(1):45-59. https://doi.org/10.1016/S03043770(00)00105-4

MacFarlane GR, Burchett MD (2001) Photosynthetic pigments and peroxidase activity as indicators of heavy metal stress in the grey mangrove, Avicennia marina (Forsk.) Vierh. Mar Pollut Bull 42(3):233-240. https://doi.org/10.1016/S0025-326X(00)00147-8

MacFarlane GR, Burchett MD (2002) Toxicity, growth and accumulation relationships of copper, lead and zinc in the grey mangrove Avicennia marina (Forsk.) Vierh. Mar Environ Res 54(1):65-84. https://doi.org/10.1016/S0141-1136(02)00095-8

MacFarlane GR, Pulkownik A, Burchett MD (2003) Accumulation and distribution of heavy metals in the grey mangrove, Avicennia marina (Forsk.)Vierh.: biological indication potential. Environ
Pollut 123(1):139-151. https://doi.org/10.1016/S0269-7491(02) 00342-1

MacFarlane GR, Kollerr CE, Blomberg SP (2007) Accumulation and partitioning of heavy metals in mangroves: a synthesis of fieldbased studies. Chemosphere 69(9):1454-1464. https://doi.org/ 10.1016/j.chemosphere.2007.04.059

Marchand C, Fernandez JM, Moreton B (2016) Trace metal geochemistry in mangrove sediments and their transfer to mangrove plants (New Caledonia). Sci Total Environ 562:216-227. https://doi. org/10.1016/j.scitotenv.2016.03.206

Marschner H (1991) Mechanism of adaptation of plants to acid soils. Plant Soil 134:1-20. https://doi.org/10.1007/BF00010712

Miao SY, Chen GZ, DeLaune RD, Jugsujinda A (2007) Partitioning and removal of $\mathrm{Cd}$ and $\mathrm{Mn}$ using a simulated mangrove wastewater treatment system. J Environ Sci Health A Tox Hazard Subst Environ Eng 42(4):405-411. https://doi.org/10.1080/10934 520601187674

Morita A, Yanagisawa O, Takatsu S, Maeda S, Hiradate S (2008) Mechanism for the detoxification of aluminum in roots of tea plant (Camellia sinensis (L.) Kuntze). Phytochemistry 69(1):147-153. https://doi.org/10.1016/j.phytochem.2007.06.007

Nahar K, Hasanuzzaman M, Suzuki T, Fujita M (2016) Polyaminesinduced aluminum tolerance in mung bean: a study on antioxidant defense and methylglyoxal detoxification systems. Ecotoxicology 26:58-73. https://doi.org/10.1007/s10646-016-1740-9

NOAA/ESRL (2019) www.esrl.noaa.gov/gmd/ccgg/trends. Accessed 29 May 2020

Ozturk F, Duman F, Leblebici Z, Temizgul R (2010) Arsenic accumulation and biological responses of watercress (Nasturtium officinale R. Br.) exposed to arsenite. Environ Exp Bot 69(2):167-174. https://doi.org/10.1016/j.envexpbot.2010.03.006

Panda SK, Baluska F, Matsumoto H (2009) Aluminum stress signaling in plants. Plant Signal Behav 4(7):592-597. https://doi.org/10. 4161/psb.4.7.8903

Parida AK, Das AB, Mittra B (2004) Effects of salt on growth, ion accumulation, photosynthesis and leaf anatomy of the mangrove, Bruguiera parviflora. Trees 18:167-174. https://doi.org/10.1007/ s00468-003-0293-8

Pred M, Cox ME (2002) Trace metal occurrence and distribution in sediments and mangroves, Pumicestone region, southeast Queensland. Australia Environ Int 28(5):433-449. https://doi. org/10.1016/S0160-4120(02)00074-0

Radotić K, Dučić T, Mutavdžić D (2000) Changes in peroxidase activity and isoenzymes in spruce needles after exposure to different concentrations of cadmium. Environ Exp Bot 44(2):105-113. https://doi.org/10.1016/S0098-8472(00)00059-9

Ramos e Silva CA, da Silva AP, de Oliveira SR (2006) Concentration, stock and transport rate of heavy metals in a tropical red mangrove, Natal, Brazil. C. A. Mar Chem 99 (1-4):2-11. https://doi. org/10.1016/j.marchem.2005.09.010

Ravikumar S, Williams GP, Shanthy S, Gracelin NA, Babu S, Parimala PS (2007) Effect of heavy metals ( $\mathrm{Hg}$ and $\mathrm{Zn}$ ) on the growth and phosphate solubilising activity in halophilic phosphobacteria isolated from Manakudi mangrove. J Environ Biol 28(1):109-114

Reef R, Feller IC, Lovelock CE (2010) Nutrition of mangroves. Tree Physiol 30:1148-1160

Ryan PR, Ditomaso JM, Kochian LV (1993) Aluminium toxicity in roots-an investigation of spatial sensitivity and the role of the root cap. J Exp Bot 44(2):437-446. https://doi.org/10.1093/jxb/ 44.2.437

Sabine CL, Feely RA, Gruber N, Key RM, Lee K, Bullister JL, Wanninkhof R, Wong CS, Wallace DWR, Tilbrook B, Millero FJ, Peng T-H, Kozyr A, Ono T, Rios AF (2004) The oceanic sink for anthropogenic $\mathrm{CO}_{2}$. Science 305(5682):367-371. https://doi. org/10.1126/science. 1097403 
Samac DA, Tesfaye M (2003) Plant improvement for tolerance to aluminum in acid soils-a review. Plant Cell Tiss Org 75:189-207. https://doi.org/10.1023/A:1025843829545

Shah K, Kumar RG, Verma S, Dubey RS (2001) Effect of cadmium on lipid peroxidation, superoxide anion generation and activities of antioxidant enzymes in growing rice seedlings. Plant Sci 161(6):1135-1144. https://doi.org/10.1016/S0168-9452(01) 00517-9

Sharma SS, Dietz KJ (2006) The significance of amino acids and amino acid-derived molecules in plant responses and adaptation to heavy metal stress. J Exp Bot 57(4):711-726. https://doi.org/ 10.1093/jxb/erj073

Sharma SS, Schat H, Vooijs R (1998) In vitro alleviation of heavy metal-induced enzyme inhibition by proline. Phytochemistry 49(6):1531-1535. https://doi.org/10.1016/S0031-9422(98) 00282-9

Siegenthaler U, Stocker TF, Monnin E, Lüthi D, Schwander J, Stauffer B, Raynaud D, Barnola J-M, Fischer H, Masson-Delmotte V, Jouzel J (2005) Stable Carbon Cycle-Climate Relationship During the Late Pleistocene. Science 310(5752):1313-1317. https:// doi.org/10.1126/science. 1120130

Sippo JZ, Maher DT, Tait DR, Holloway C, Santos IR (2016) Are mangroves drivers or buffers of coastal acidification? Insights from alkalinity and dissolved inorganic carbon export estimates across a latitudinal transect. Global Biogeochem Cy 30(5):753-766. https://doi.org/10.1002/2015GB005324

Sivaguru M, Horst WJ (1998) The distal part of the transition zone is the most aluminum sensitive apical root zone of maize. Plant Physiol 116(1):155-163. https://doi.org/10.1104/pp.116.1.155

Sivaguru M, Ezaki B, He ZH, Tong HY, Osawa H, Baluška F, Volkmann D, Matsumoto H (2003) Aluminum-induced gene expression and protein localization of a cell wall-associated receptor kinase in Arabidopsis. Plant Physiol 132(4):2256-2266. https:// doi.org/10.1104/pp.103.022129

Sparks DL (2003) The Chemistry of Soil Acidity. In: Environmental Soil Chemistry (Second Edition). pp 267-283. doi:https://doi. org/10.1016/b978-012656446-4/50009-8

Takemura T, Hanagata N, Sugihara K, Baba S, Karube I, Dubinsky Z (2000) Physiological and biochemical responses to salt stress in the mangrove, Bruguiera gymnorrhiza. Aquat Bot 68(1):15-28. https://doi.org/10.1016/S0304-3770(00)00106-6

Tam NFY (1998) Effects of wastewater discharge on microbial populations and enzyme activities in mangrove soils. Environ Pollut 102(2-3):233-242. https://doi.org/10.1016/S0269-7491(98) 00084-0

Tam NFY, Wong YS (1996) Retention and distribution of heavy metals in mangrove soils receiving wastewater. Environ Pollut 94(3):283-291. https://doi.org/10.1016/S0269-7491(96)00115-7

Tamás L, Huttová J, Mistrík I (2003) Inhibition of Al-induced root elongation and enhancement of Al-induced peroxidase activity in Al-sensitive and Al-resistant barley cultivars are positively correlated. Plant Soil 250:193-200. https://doi.org/10.1023/A: 1022863211942

Uriu-Adams JY, Keen CL (2005) Copper, oxidative stress, and human health. Mol Aspects Med 26(4-5):268-298. https://doi.org/10. 1016/j.mam.2005.07.015

USEPA (2020) Understanding the Science of Ocean and Coastal Acidification. United States Environmental Protection Agency. https:// www.epa.gov/ocean-acidification/understanding-science-oceanand-coastal-acidification. Accessed 2020.07.06

Van der Vliet L, Peterson C, Hale B (2007) Cd accumulation in roots and shoots of durum wheat: the roles of transpiration rate and apoplastic bypass. J Exp Bot 58(11):2939-2947. https://doi.org/ $10.1093 /$ jxb/erm119
Vranová E, Inzé D, Van Breusegem F (2002) Signal transduction during oxidative stress. J Exp Bot 53(372):1227-1236. https://doi. org/10.1093/jexbot/53.372.1227

Walsh GE, Ainsworth KA, Rigby R (1979) Resistance of red mangrove (Rhizophora mangle L.) seedlings to lead, cadmium and mercury. Biotropica 11(1):22-27. https://doi.org/10.2307/2388167

Wang H, Xiao X, Yang M, Gao Z, Zang J, Fu X, Chen Y (2014) Effects of salt stress on antioxidant defense system in the root of Kandelia candel. Bot Stud 55:57. https://doi.org/10.1186/ s40529-014-0057-3

Wang A, Wang M, Liao Q, He X (2016) Characterization of Cd translocation and accumulation in 19 maize cultivars grown on Cd-contaminated soil: implication of maize cultivar selection for minimal risk to human health and for phytoremediation. Environ Sci Pollut Res 23:5410-5419. https://doi.org/10.1007/ s11356-015-5781-Z

Wei SD, Zhou HC, Lin YM (2010) Antioxidant activities of extract and fractions from the hypocotyls of the mangrove plant Kandelia candel. Int J Mol Sci 11(10):4080-4093. https://doi.org/10. 3390/ijms 11104080

Xing J, Pan D, Wang L, Tan F, Chen W (2019) Proteomic and physiological responses in mangrove Kandelia candel roots under short-term high-salinity stress. Turk J Biol 43:314-325. https:// doi.org/10.3906/biy-1906-22

Yan L, Chen G (2007) Physiological adaptability of three mangrove species to salt stress. Acta Ecol Sin 27(6):2208-2214. https://doi. org/10.1016/S1872-2032(07)60052-3

Yang JL, Li YY, Zhang YJ, Zhang SS, Wu YR, Wu P, Zheng SJ (2008) Cell wall polysaccharides are specifically involved in the exclusion of aluminum from the rice root apex. Plant Physiol 146(2):602-611. https://doi.org/10.1104/pp.107.111989

Ye Y, Chen YP, Chen GC (2013) Litter production and litter elemental composition in two rehabilitated Kandelia obovata mangrove forests in Jiulongjiang Estuary, China. Mar Environ Res 83:63-72. https://doi.org/10.1016/j.marenvres.2012.10.011

Yin L, Huang J, Huang W, Li D, Wang G, Liu Y (2005) Microcystin-RR-induced accumulation of reactive oxygen species and alteration of antioxidant systems in tobacco BY-2 cells. Toxicon 46(5):507-512. https://doi.org/10.1016/j.toxicon.2005.06.015

Zhang FQ, Wang YS, Lou ZP, Dong JD (2007) Effect of heavy metal stress on antioxidative enzymes and lipid peroxidation in leaves and roots of two mangrove plant seedlings (Kandelia candel and Bruguiera gymnorrhiza). Chemosphere 67(1):44-50. https://doi. org/10.1016/j.chemosphere.2006.10.007

Zhao Y, Wu J, Shang D, Ning J, Zhai Y, Sheng X, Ding H (2015) Subcellular distribution and chemical forms of cadmium in the edible seaweed, Porphyra yezoensis. Food Chem 168:48-54. https://doi. org/10.1016/j.foodchem.2014.07.054

Zhou YW, Zhao B, Peng YS, Chen GZ (2010) Influence of mangrove reforestation on heavy metal accumulation and speciation in intertidal sediments. Mar Pollut Bull 60(8):1319-1324. https:// doi.org/10.1016/j.marpolbul.2010.03.010

Zouari M, Ahmed CB, Zorrig W, Elloumi N, Rabhi M, Delmail D, Rouina BB, Labrousse P, Abdallah FB (2016) Exogenous proline mediates alleviation of cadmium stress by promoting photosynthetic activity, water status and antioxidative enzymes activities of young date palm (Phoenix dactylifera $\mathrm{L}$.). Eco Env Saf 128:100-108. https://doi.org/10.1016/j.ecoenv.2016.02.015

Publisher's note Springer Nature remains neutral with regard to jurisdictional claims in published maps and institutional affiliations. 